\title{
Transnational Capital/Labour Flows Adapting Labour Market Policy to a Transformed Employment Structure
}

\author{
Meiling Lin \\ Department of Social Science, National Open University, Taipei, Taiwan, R.O.C.
}

Email address:

paulina@kcg.gov.tw

To cite this article:

Meiling Lin. Transnational Capital/Labour Flows Adapting Labour Market Policy to a Transformed Employment Structure. Social Sciences. Vol. 7, No. 3, 2018, pp. 94-114. doi: 10.11648/j.ss.20180703.11

Received: January 17, 2018; Accepted: January 30, 2018; Published: April 13, 2018

\begin{abstract}
The shift towards recognition of a capital-labour flows have occurred within the broader context of a globalized knowledge economy and a global race for skills. Change in a country's employment structure is shaped by the evolution of skill supplies, implies that educational expansion and migration flows are crucial to understand occupational change. The local communities, Taiwan is in competition for its share of the intellectual capital and for the best skilled migrants. The aim is to disentangle the strategy applied by Taiwan to adapt its national labour markets to increasing globalization and flexibility demands. The paper is presented as follows. First, to compare national patterns of job growth in Taiwan, extending the discussion of the reach of job polarization. Second, to examine differential patterns, building on the analysis of educational patterns of employment growth. Third, to go about understanding the relationship between capital flows, labour flows and em/migrant resettlement patterns. The impact of economic globalization has on the flows of the highly educated, and documents incentive programs put into place by the government to tap highly educated talent abroad are assessed. A final summary reflects on the key finding, its contribution to the research arena, as well as open questions for future research. The paper delivers both quantitative and qualitative data as well as an account of the relevant labour market reforms.
\end{abstract}

Keywords: Capital/Labour Flows, Cross Border, Labour Market, Employment Structure

\section{Introduction}

International economic links have strengthened due to growing trade and capital flows. Cross-border financial flows have become an important feature of the global economy, reflecting global financial integration. The global financial crisis has reinforced the financial linkages across countries, and the resulting rise in volatility generated by capital flows. Processes such as outsourcing, deregulation of the labour market, and growing demands for employee flexibility have combined to create an imperative of high mobility. Contemporary work calls for flexibility as the need for constant reskilling. The economic activity of the population can be improved by enhancing the labour force's pool of qualifications and investing more in human capital. While the goal of political reform and economic growth is a knowledge-based society, employees tend to be geographically flexible and mobile, contributing to the diversity of the workforce. The importance of investigating the social context and personal circumstances of high mobility is underlined, and forces to think about the importance of economic, social, and political differences among territorially defined states versus the benefits of crossborder integration.

Innovation is the key factor in promoting competitiveness in a globalizing knowledge economy, and labor market mobility can be important for generating diversity of knowledge. At the heart of these changes was to produce available labor, to promote an entrepreneurial way of thinking, and to broaden the worker's capacity to acquire entrepreneurial competences. It is necessary to think about new ways to develop a high qualification level among the workforce. Strategies of youth, education, labour market and social policy emphasise the necessity to promote skills and competencies of young people that are seen as conducive to improving the economic productivity and competitiveness. The increased competition on labour markets and the shift towards the knowledge society will create demand for highly skilled labour, and increase the importance of education on 
the labour market. Employment and education have become indicators of the conditions young people are facing during the period of financial crises and socio-political reform. It deserves to explore how educational strategies are implemented and if they enable young people to convert knowledge and skills into capabilities to act as participating active citizens.

The aging of the population and the evolution of the labour force as well as the migratory policy are explored. Indicators of human capital and industry composition perform, talent, and technology explain job and income growth and job instability. Without structural changes to global economic systems and broader opportunities for reskilling, the future of employment is dismal for many. The important feature of an educational system is the strength of the institutional linkages between education and labor market. Young people are confronted with an increasing fragmentation and flexibility and will have to cope with the rotation between diverse work fields and temporary flexible employment. The paper proposes alternative ways of rethinking the impact of mobility to embed young people's experiences of international mobility within a world characterized by diversity. This intertwining of the global and the local is discussed. The challenge is combining quantitative and qualitative data according to the methodological design and in the analytical phase. The article concludes with some policy recommendations.

\section{Method}

\subsection{Aims \& Underlying Assumptions}

The important problems of the labour market will be the shrinking of the labour force and then aging of the labour force. This paper covers the period 1960-2016 and are formulated in terms of aging, capital/labour flows and em/migrant resettlement patterns. These predictions anticipate different effects depending on whether one considers the impact of aging on capital versus labour markets. In particular, capital flows seeks out young workers, locations with higher savings rates, and countries with lower social security taxes. This drives capital out of an aging country as investors seek low-cost workers. It is hope to find differing effects from the capital and labour market implications of aging. In order to explore how to enable young people to be capable as participants in labour markets, the factors that promote young people's capabilities for education and for work, have to be considered altogether. In particular, there has been a shift from labor market flexibility to the flexibility of educational systems. The fight against youth unemployment should start at school, not after school.

The paper is structured as follows. Section 1 consists of the themes: (a) capital and labour market implications of aging; (b) capital flows and impact of financial globalization; (c) educational patterns of employment growth; (d) relationship between capital/labour flows and em/migrant resettlement patterns and (e) impact economic globalization has on the flows of the highly educated. Section 2 describes the data and empirical methodology used. Section 3 discusses the empirical evidence for the local communities, Taiwan. Section 4 summarizes the main findings and policy implications. The paper summarizes current thinking on what adapting labour market policy to the transformed employment structure can best address these issues. Some final remarks conclude the paper after discussing the main implications. The paper highlights the challenges posed by flexicurity and the integration of the educational system to the labor market. An emerging new form of social inequality as a consequence of changing education policies would also been explained.

\subsection{The Data Sources and Measures}

The author draws on empirical evidences to analyze the role of macroeconomic factors - technological change and globalization, and the role of structural policies - education policy, as well as labor and product market regulation, in shaping the transnational capital/labour flows. The importance of using mixed methods (i.e. combining both quantitative and qualitative methods) and complementing quantitative information by providing a deeper understanding about the "adapting labour market policy to a transformed employment structure" has been underlined. There is the necessity to frame and extend the analysis to other relevant qualitative aspects such as "capital and labour market implications of aging", "educational patterns of employment growth", "relationship between capital/labour flows and em/migrant resettlement patterns", and "impact economic globalization has on the flows of the highly educated". Social space, called the volume of global capital, is a product of the correlation between these variables that include education, income, and occupational status. The data used in this study comes from the database "Directorate General of Budget, Accounting and Statistics (DGBAS)" and "Workforce Development Agency, Ministry of Labor (MOL)", provided by the Executive Yuan, R. O. C.. Using a time-series analysis to explore the relationship between changes in public policy and their effects on the adapting labour market policy to a transformed employment structure, has a varying impact on the incidence of those demands. This paper highlights inequality trends and assesses different policy approaches to reduce labor and disposable income inequality.

\subsection{Theoretical Foundations}

One feature of modern economies is the mobility of financial capital [1]. Financial globalization and cross-border capital raisings catalyze domestic financial market development and improve institutional governance [2]. Access to foreign capital would help the emerging markets grow faster [3]. Rapid economic growth will open up new possibilities of economic cooperation, and there will be an increased flow of people [4]. There is increasing competition to fight for the best intellectual capital [5]. In order to maintain economic prosperity, countries will have to rely on 
immigration [6]. Such a reallocation poses a challenge for the labour market, since it requires mobility of workers across sectors [7]. Technological progress and economic activities are becoming skill-intensive, and will create demand for skilled labour force [8]. Active labour market policies promise investments in the potentials of individuals to promote labour and social integration [9]. Employment volatility and a globalized labor market will have an impact on future jobs [10]. Mobility reveals society dynamics more generally [11]. Mobility across organizational borders contributes to professional and social relationships [12]. Facilitating intergenerational mobility allows society to tap the talents of people [13]. Jobs requiring mobility serves as an instrument to accumulate human capital [14].

As globalization has proceeded, locals have become more prominent economic governance actors [15]. The impact of knowledge- intensive service firms is derived from their capacity to facilitate innovation [16]. The diversity of industries promotes the knowledge spillovers, the innovation and economic growth [17]. Foreign direct investment can benefit host economies through knowledge spillovers [18]. Geographical proximity enables firms to exchange knowledge among each other [19]. Clusters generate knowledge spillovers and draw upon a pool of skilled labor [20]. Clusters are becoming more vital in the global market where localities have to face with an increasing competition fostered by high mobility [21]. The clustering effect of human capital focuses on the capacity of localities to enable new knowledge to circulate more efficiently [22]. The knowledge-based capital is a source of regional innovation capacity which supports that regions differ in the way they capture talents [23]. Creative economy is expressed in the ability to create and circulate intellectual capital, with the potential to generate income and jobs [24]. With businesses making transactions beyond their borders, they want employees to maximize their pro-fit [25]. Jobs will be created for the well educated and highly skilled part of the workforce [26]. Competitive advantage is increasingly derived from investments in human creativity and innovation.

Human capital is used as a variable to explain differences and it is a proxy of education of individuals [27]. Education contributes to economic productivity through transmission of knowledge, national workforce development, and global competitiveness. Equity in access to higher education is positively correlated with human capital development and with the economic competitiveness of nations [28].
Knowledge-based economy highlighted the importance of investments in education [29]. Those individual possessing greater human capital are the ones more likely to recognize those opportunities, leading to economic change [30]. A country's productivity and economic growth are seen to depend on the education possessed by its labour force [31]. Education is a common that provides individuals with knowledge to deal with changes [32]. As the level of education of individuals increases, the more they participate in the workforce, and the risk of unemployment declines. The importance of educational resources is not concerned with increasing economic productivity but also with reducing inequalities and empowering young people to lead integrated lives [33].

\section{Result: Local Community in Its Global Context}

In the context of an increasingly globalized world which itself is undergoing a period of crisis and uncertainty, gross flows raise financial risks. A domestic credit boom may be amplified by cross-border debt inflows into the domestic banking system. By expenditures on gross domestic product, the amount (Million $\mathrm{N}$. T. \$) of gross capital formation declines from 3,217,027 in 2008 to $2,580,249$ in $2009(-24.68 \%)$, and then $3,524,645$ in 2010 ; the amount of GDP declines from 13,150,950 in 2008 to $12,961,656$ in $2009(-1.46 \%)$, and then $14,119,213$ in 2010 , which is shown in Table 1. At the peak, gross capital flows in Taiwan exceeded $30 \%$ of GDP. The collapse in capital flows in 2008-2009 was remarkable, falling to just $4.91 \%$ of GDP. According to the contributions to percent change in real Gross Domestic Product by expenditures, the rate of economic growth declines from 0.7 in 2008 to -1.57 in 2009, and then 10.63 in 2010; the percentage of exports of goods and services decrease from 0.39 in 2008 to 5.9 in 2009, and then 15.5 in 2010; the percentage of inports of goods and services decrease from -2.55 in 2008 to -8.59 in 2009, and then 14.4 in 2010, which is shown in Table 2. Capital inflows can make Taiwan more vulnerable to financial crisis. The worry on the financial stability side is that large inflows may lead to excessive foreign borrowing and foreign currency exposure, adding fuel to a domestic credit boom and domestic asset price bubbles. Dealing with capital flows requires lowering interest rates to discourage large inflows, but low interest rates are also expansionary for the domestic economy and may not be the right policy choice for an inflation-targeting central bank.

Table 1. Expenditures on Gross Domestic Product in Taiwan, End of 1981-2016.

\begin{tabular}{|c|c|c|c|c|c|c|c|}
\hline Year & $\begin{array}{l}\text { Gross Capital } \\
\text { Formation } \\
\end{array}$ & $\begin{array}{l}\text { Gross Fixed } \\
\text { Capital Formation }\end{array}$ & $\begin{array}{l}\text { Changes in } \\
\text { Inventories }\end{array}$ & $\begin{array}{l}\text { Exports of Goods } \\
\text { and Services }\end{array}$ & $\begin{array}{l}\text { Imports of Goods } \\
\text { and Services }\end{array}$ & GDP & $\begin{array}{l}\text { Net Factor Income } \\
\text { from Abroad }\end{array}$ \\
\hline 1981 & 548,768 & 512,978 & 35,790 & 917,245 & 881,965 & $1,805,043$ & $-9,653$ \\
\hline 1982 & 508,185 & 519,884 & $-11,699$ & 947,554 & 851,310 & $1,938,394$ & -682 \\
\hline 1983 & 552,276 & 518,980 & 33,296 & $1,117,529$ & 938,623 & $2,170,005$ & 3,256 \\
\hline 1984 & 590,421 & 549,267 & 41,154 & $1,322,253$ & $1,071,559$ & $2,418,884$ & 29,975 \\
\hline 1985 & 529,447 & 529,967 & -520 & $1,345,492$ & $1,018,088$ & $2,536,012$ & 47,154 \\
\hline 1986 & 614,762 & 594,404 & 20,358 & $1,660,994$ & $1,113,571$ & $2,966,911$ & 76,962 \\
\hline 1988 & $1,044,229$ & 845,044 & 199,185 & $1,917,113$ & $1,674,307$ & $3,615,319$ & 97,374 \\
\hline 1989 & $1,029,656$ & 992,183 & 37,473 & $1,957,029$ & $1,710,910$ & $4,033,071$ & 100,769 \\
\hline
\end{tabular}




\begin{tabular}{|c|c|c|c|c|c|c|c|}
\hline Year & $\begin{array}{l}\text { Gross Capital } \\
\text { Formation } \\
\end{array}$ & $\begin{array}{l}\text { Gross Fixed } \\
\text { Capital Formation } \\
\end{array}$ & $\begin{array}{l}\text { Changes in } \\
\text { Inventories }\end{array}$ & $\begin{array}{l}\text { Exports of Goods } \\
\text { and Services }\end{array}$ & $\begin{array}{l}\text { Imports of Goods } \\
\text { and Services }\end{array}$ & GDP & $\begin{array}{l}\text { Net Factor Income } \\
\text { from Abroad }\end{array}$ \\
\hline 1990 & $1,142,092$ & $1,111,414$ & 30,678 & $2,020,064$ & $1,833,356$ & $4,480,288$ & 117,307 \\
\hline 1991 & $1,303,548$ & $1,239,534$ & 64,014 & $2,302,504$ & $2,116,633$ & $5,023,763$ & 135,550 \\
\hline 1992 & $1,583,571$ & $1,491,975$ & 91,596 & $2,347,562$ & $2,265,853$ & $5,614,679$ & 120,762 \\
\hline 1993 & $1,778,885$ & $1,715,984$ & 62,901 & $2,632,257$ & $2,547,194$ & $6,205,338$ & 114,044 \\
\hline 1994 & $1,898,164$ & $1,843,656$ & 54,508 & $2,857,679$ & $2,763,130$ & $6,784,442$ & 107,517 \\
\hline 1995 & $2,072,405$ & $2,027,897$ & 44,508 & $3,412,791$ & $3,310,709$ & $7,396,650$ & 110,919 \\
\hline 1996 & $2,043,855$ & $2,033,277$ & 10,578 & $3,692,075$ & $3,446,367$ & $8,036,590$ & 109,502 \\
\hline 1997 & $2,317,181$ & $2,231,680$ & 85,501 & $4,060,689$ & $3,900,409$ & $8,717,241$ & 89,611 \\
\hline 1998 & $2,571,393$ & $2,482,879$ & 88,514 & $4,352,253$ & $4,264,488$ & $9,381,141$ & 68,551 \\
\hline 1999 & $2,598,205$ & $2,540,878$ & 57,327 & $4,554,722$ & $4,325,339$ & $9,815,595$ & 90,518 \\
\hline 2000 & $2,815,099$ & $2,722,595$ & 92,504 & $5,373,337$ & $5,167,343$ & $10,351,260$ & 139,558 \\
\hline 2001 & $2,175,715$ & $2,238,591$ & $-62,876$ & $4,942,685$ & $4,413,478$ & $10,158,209$ & 192,024 \\
\hline 2002 & $2,241,850$ & $2,285,679$ & $-43,829$ & $5,427,124$ & $4,691,827$ & $10,680,883$ & 242,502 \\
\hline 2003 & $2,377,923$ & $2,365,673$ & 12,250 & $5,924,171$ & $5,188,584$ & $10,965,866$ & 328,873 \\
\hline 2004 & $2,954,277$ & $2,853,709$ & 100,568 & $6,982,430$ & $6,580,684$ & $11,649,645$ & 372,099 \\
\hline 2005 & $2,957,842$ & $2,924,286$ & 33,556 & $7,329,793$ & $6,825,273$ & $12,092,254$ & 290,866 \\
\hline 2006 & $3,110,995$ & $3,063,352$ & 47,643 & $8,316,084$ & $7,588,087$ & $12,640,803$ & 311,699 \\
\hline 2007 & $3,221,482$ & $3,205,121$ & 16,361 & $9,349,494$ & $8,283,905$ & $13,407,062$ & 332,766 \\
\hline 2008 & $3,217,027$ & $3,045,433$ & 171,594 & $9,230,775$ & $8,548,202$ & $13,150,950$ & 314,646 \\
\hline 2009 & $2,580,249$ & $2,761,737$ & $-181,488$ & $7,827,336$ & $6,677,161$ & $12,961,656$ & 413,994 \\
\hline 2010 & $3,524,645$ & $3,335,881$ & 188,764 & $10,013,538$ & $9,015,369$ & $14,119,213$ & 429,639 \\
\hline 2011 & $3,382,866$ & $3,346,945$ & 35,921 & $10,419,700$ & $9,456,937$ & $14,312,200$ & 388,372 \\
\hline 2012 & $3,304,160$ & $3,282,131$ & 22,029 & $10,345,375$ & $9,252,005$ & $14,686,917$ & 454,191 \\
\hline 2013 & $3,360,196$ & $3,378,731$ & $-18,535$ & $10,579,884$ & $9,200,363$ & $15,230,739$ & 423,849 \\
\hline 2014 & $3,521,157$ & $3,493,834$ & 27,323 & $11,254,123$ & $9,594,908$ & $16,111,867$ & 470,538 \\
\hline 2015 & $3,513,112$ & $3,493,267$ & 19,845 & $10,775,522$ & $8,619,902$ & $16,770,671$ & 530,726 \\
\hline 2016 & $3,569,704$ & $3,584,910$ & $-15,206$ & $10,771,164$ & $8,686,158$ & $17,152,093$ & 530,341 \\
\hline
\end{tabular}

Source: Directorate General of Budget, Accounting and Statistics (DGBAS) of Executive Yuan, R. O. C. (Taiwan) Unit: Million N. T. \$

Table 2. Contributions to Percent Change in Real Gross Domestic Product by Expenditures in Taiwan, End of 1981 -2016.

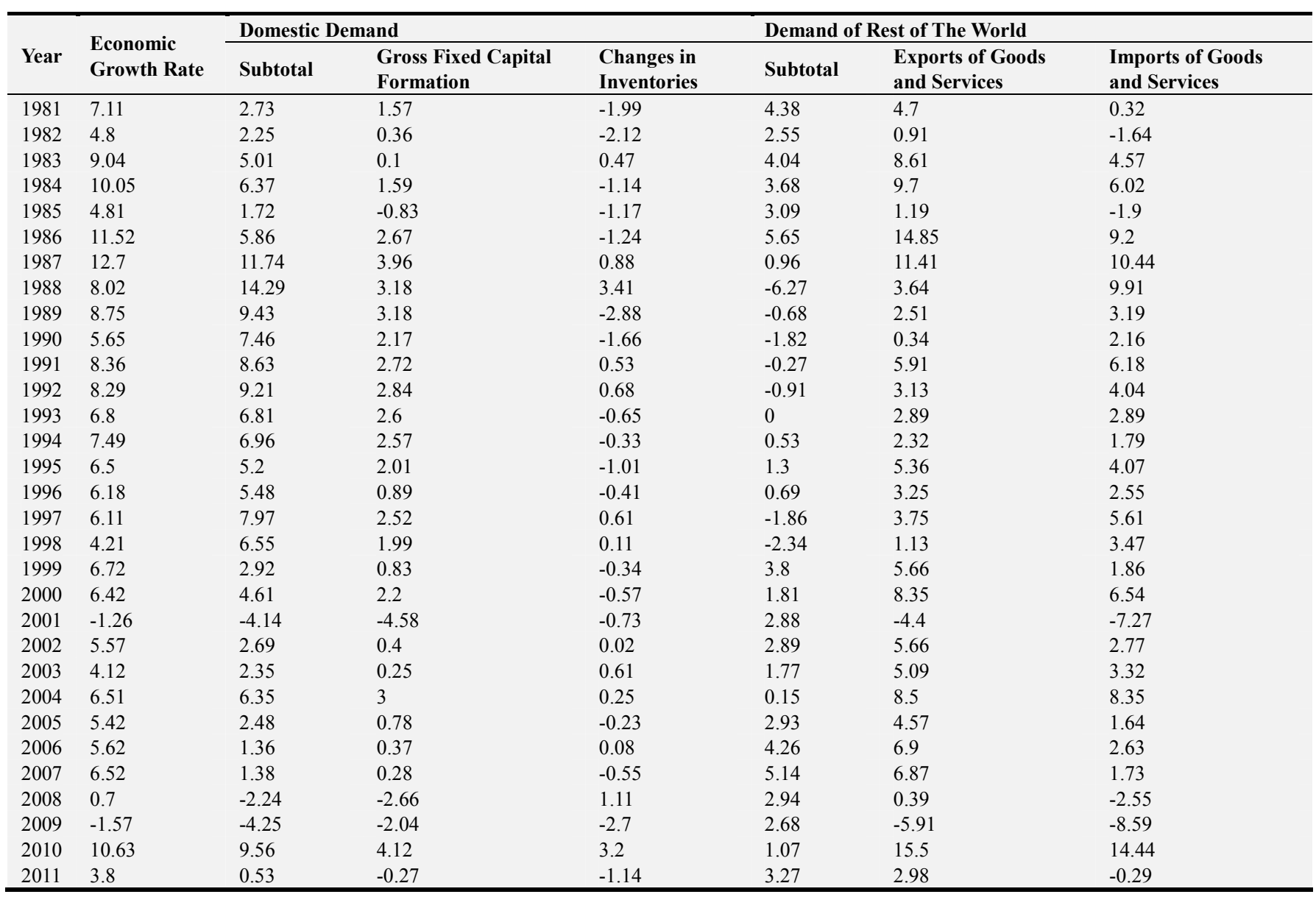




\begin{tabular}{llllllll}
\hline \multirow{2}{*}{ Year } & $\begin{array}{l}\text { Economic } \\
\text { Growth Rate }\end{array}$ & Domestic Demand & & \multicolumn{2}{c}{ Demand of Rest of The World } \\
\cline { 3 - 7 } & Subtotal & $\begin{array}{l}\text { Gross Fixed Capital } \\
\text { Formation }\end{array}$ & $\begin{array}{l}\text { Changes in } \\
\text { Inventories }\end{array}$ & Subtotal & $\begin{array}{l}\text { Exports of Goods } \\
\text { and Services }\end{array}$ & $\begin{array}{l}\text { Imports of Goods } \\
\text { and Services }\end{array}$ \\
\hline 2012 & 2.06 & 0.59 & -0.61 & -0.12 & 1.47 & 0.3 & -1.18 \\
2013 & 2.2 & 1.88 & 1.18 & -0.46 & 0.32 & 2.46 & 2.14 \\
2014 & 4.02 & 3.37 & 0.46 & 0.52 & 0.65 & 4.07 & 3.42 \\
2015 & 0.81 & 1.71 & 0.36 & -0.03 & -0.91 & -0.26 & 0.65 \\
2016 & 1.41 & 1.94 & 0.47 & -0.26 & -0.53 & 1.24 & 1.77 \\
\hline
\end{tabular}

Source: Directorate General of Budget, Accounting and Statistics (DGBAS) of Executive Yuan, R. O. C. (Taiwan)

Unit: Percentage Points

Taiwan exports have fared relative to world exports, and Taiwan's market specialization is towards products and markets which are dynamic. According to gross domestic product by kind of activity, the amount (Million N. T. \$) of information and communication develops from 34,377 in 1981 to 499,672 in 2016, and its\% of GDP develops from.0190 in 1981 to.0291 in 2016; the amount of finance and insurance develops from 68,995 in 1981 to $1,118,794$ in 2016, and its\% of GDP develops from.0382 in 1981 to.0652 in 2016; the amount of professional, scientific and technical services develops from 19,733 in 1981 to 358,525 in 2016, and its\% of GDP develops from.0109 in 1981 to.0209 in 2016; the amount of education develops from 48,103 in 1981 to 702,675 in 2016 , and its\% of GDP develops from.0266 in 1981 to.0410 in 2016; the amount of ICT industry develops from 76,106 in 1981 to 2,864,275 in 2016, and its\% of GDP develops from .0422 in 1981 to.1670 in 2016, which is shown in Table 3. Taiwan has a revealed comparative advantage in the product groups: high skill and technologyintensive manufactures, high-tech knowledge-intensive services and knowledge-intensive services. The first 2 groups are ones where multinational investment dominates economic activity, and the third also has a strong multinational presence. Taiwan attracts foreign direct investment (FDI) as a means of generating higher economic growth by providing to domestic firms both a source of capital financing and productivity externalities. Governments offer incentives calculated to attract foreign firms and foster relationships between multinational enterprises (MNEs) and local firms. As the government faces the criticism for the shortterm capital inflows, it would have been more hesitant to engage in the fiscal expansion.

Table 3. Gross Domestic Product by Kind of Activity in Taiwan, End of 1981-2016.

\begin{tabular}{|c|c|c|c|c|c|c|}
\hline & \multicolumn{6}{|c|}{ Gross Domestic Product_Current Price (Million N. T. \$) } \\
\hline & \multicolumn{2}{|l|}{1981} & \multicolumn{2}{|l|}{1991} & \multicolumn{2}{|l|}{2008} \\
\hline & data & $\%$ of GDP & data & $\%$ of GDP & data & $\%$ of GDP \\
\hline A. Agriculture, Forestry, Fishing and Animal Husbandry & 132,689 & .0735 & 182,509 & .0363 & 201,656 & .0153 \\
\hline B. Mining and Quarrying & 13,798 & .0076 & 14,236 & .0028 & 23,564 & .0018 \\
\hline C. Manufacturing & 589,905 & .3268 & $1,548,505$ & .3082 & $3,567,420$ & .2713 \\
\hline D. Electricity and Gas Supply & 75,725 & .0420 & 139,386 & .0277 & 39,959 & .0030 \\
\hline F. Construction & 98,290 & .0545 & 215,167 & .0428 & 355,400 & .0270 \\
\hline G. Wholesale and Retail Trade & 226,275 & .1254 & 649,116 & .1292 & $2,319,485$ & .1764 \\
\hline H. Transportation and Storage & 77,212 & .0428 & 219,326 & .0437 & 388,038 & .0295 \\
\hline I. Accommodation and Food Services & 15,548 & .0086 & 80,772 & .0161 & 257,029 & .0195 \\
\hline J. Information and Communication & 34,377 & .0190 & 116,469 & .0232 & 454,657 & .0346 \\
\hline K. Finance and Insurance & 68,995 & .0382 & 334,155 & .0665 & 912,828 & .0694 \\
\hline M. Professional, Scientific and Technical Services & 19,733 & .0109 & 73,705 & .0147 & 293,136 & .0223 \\
\hline N. Support Services & 11,247 & .0062 & 27,021 & .0054 & 192,776 & .0147 \\
\hline $\begin{array}{l}\text { O. Public Administration and Defence }{ }_{\text {FCOmpulsory Social }} \\
\text { Security }\end{array}$ & 156,698 & .0868 & 452,952 & .0902 & 988,665 & .0752 \\
\hline P. Education & 48,103 & .0266 & 158,064 & .0315 & 630,999 & .0480 \\
\hline Q. Human Health and Social Work Services & 13,204 & .0073 & 89,744 & .0179 & 370,232 & .0282 \\
\hline R. Arts, Entertainment and Recreation & 9,042 & .0050 & 34,024 & .0068 & 111,528 & .0085 \\
\hline S. Other Services & 37,117 & .0206 & 113,494 & .0226 & 356,092 & .0271 \\
\hline Subtotal & $1,728,793$ & .9578 & $4,811,010$ & .9577 & $12,658,936$ & .9626 \\
\hline Import Duties & 76,250 & .0422 & 116,632 & .0232 & 132,563 & .0101 \\
\hline Total ( by production approach ) & $1,805,043$ & 1.0000 & $5,023,763$ & 1.0000 & $13,012,820$ & .9895 \\
\hline GDP & $1,805,043$ & 1.0000 & $5,023,763$ & 1.0000 & $13,150,950$ & 1.0000 \\
\hline By Major Activities; Agriculture & 132,689 & .0735 & 182,509 & .0363 & 201,656 & .0153 \\
\hline By Major Activities; Industry & 791,098 & .4383 & $1,950,369$ & .3882 & $4,073,510$ & .3098 \\
\hline
\end{tabular}


Table 3. Continued.

\begin{tabular}{|c|c|c|c|c|c|c|}
\hline & \multicolumn{6}{|c|}{ Gross Domestic Product_Current Price (Million N. T. \$) } \\
\hline & \multicolumn{2}{|c|}{2009} & \multicolumn{2}{|c|}{2010} & \multicolumn{2}{|l|}{2016} \\
\hline & data & $\%$ of GDP & data & $\%$ of GDP & data & $\%$ of GDP \\
\hline A. Agriculture, Forestry, Fishing and Animal Husbandry & 215,109 & .0166 & 224,828 & .0159 & 307,133 & .0179 \\
\hline B. Mining and Quarrying & 18,030 & .0014 & 19,008 & .0013 & 15,018 & .0009 \\
\hline C. Manufacturing & $3,422,636$ & .2641 & $4,090,594$ & .2897 & $5,254,060$ & .3063 \\
\hline D. Electricity and Gas Supply & 187,971 & .0145 & 182,902 & .0130 & 296,296 & .0173 \\
\hline E. Water Supply and Remediation Services & 86,432 & .0067 & 94,504 & .0067 & 112,316 & .0065 \\
\hline G. Wholesale and Retail Trade & $2,223,440$ & .1715 & $2,367,946$ & .1677 & $2,754,591$ & .1606 \\
\hline H. Transportation and Storage & 363,325 & .0280 & 427,866 & .0303 & 504,082 & .0294 \\
\hline I. Accommodation and Food Services & 267,459 & .0206 & 293,073 & .0208 & 443,360 & .0258 \\
\hline J. Information and Communication & 453,945 & .0350 & 465,419 & .0330 & 499,672 & .0291 \\
\hline K. Finance and Insurance & 797,576 & .0615 & 871,705 & .0617 & $1,118,794$ & .0652 \\
\hline L. Real Estate and Ownership of Dwellings & $1,148,078$ & .0886 & $1,188,787$ & .0842 & $1,388,749$ & .0810 \\
\hline M. Professional, Scientific and Technical Services & 293,405 & .0226 & 307,743 & .0218 & 358,525 & .0209 \\
\hline $\begin{array}{l}\text { O. Public Administration and Defence }{ }_{\text {FCCompulsory }} \\
\text { Social Security }\end{array}$ & 994,245 & .0767 & $1,034,284$ & .0733 & $1,084,030$ & .0632 \\
\hline P. Education & 646,377 & .0499 & 654,422 & .0463 & 702,675 & .0410 \\
\hline Q. Human Health and Social Work Services & 384,205 & .0296 & 392,829 & .0278 & 525,798 & .0307 \\
\hline R. Arts, Entertainment and Recreation & 115,840 & .0089 & 120,299 & .0085 & 148,703 & .0087 \\
\hline S. Other Services & 360,257 & .0278 & 372,513 & .0264 & 438,521 & .0256 \\
\hline Subtotal & $12,483,079$ & .9631 & $13,672,960$ & .9684 & $16,626,667$ & .9694 \\
\hline Import Duties & 117,195 & .0090 & 152,107 & .0108 & 199,740 & .0116 \\
\hline Total ( by production approach ) & $12,806,679$ & .9880 & $14,074,747$ & .9969 & $17,134,738$ & .9990 \\
\hline GDP & $12,961,656$ & 1.0000 & $14,119,213$ & 1.0000 & $17,152,093$ & 1.0000 \\
\hline By Major Activities; Agriculture & 215,109 & .0166 & 224,828 & .0159 & 307,133 & .0179 \\
\hline By Major Activities; Industry & $4,034,619$ & .3113 & $4,754,052$ & .3367 & $6,086,185$ & .3548 \\
\hline By Major Activities; Services & $8,556,951$ & .6602 & $9,095,867$ & .6442 & $10,741,420$ & .6262 \\
\hline ICT Industry & $1,841,564$ & .1421 & $2,111,024$ & .1495 & $2,864,275$ & .1670 \\
\hline
\end{tabular}

Source: Directorate General of Budget, Accounting and Statistics (DGBAS) of Executive Yuan, R. O. C. (Taiwan)

Unit: Million N. T. \$

The opening up of the Taiwan economy began in 1980 with the adoption of a range of policy measures, in particular relating to trade liberalization and the promotion of foreign direct investment. By major activities, the amount of agriculture develops from 132,689 in 1981 to 307,133 in 2016, and its\% of GDP develops from.0735 in 1981 to.0179 in 2016; the amount of industry develops from 791,098 in 1981 to $6,086,185$ in 2016 , and its\% of GDP develops from.4383 in 1981 to.3548 in 2016; the amount of services develops from 881,256 in 1981 to $10,741,420$ in 2016, and its\% of GDP develops from.4882 in 1981 to.6262 in 2016, which is shown in Table 3 . The industrial sector has played a major role in the transformation of the economy, with growth in manufacturing value of $3.06 \%$ GPD in 2016. The services sector has also expanded rapidly during this period, accounting in 2016 for over half of employment and output in the economy. The majority of firms are in the services sector. The proportion of Gross Domestic Product by kind of activity in the agricultural sector declined steadily between 1981 and 2016 while the proportion of Gross Domestic Product by kind of activity in industry and services grew. Since the late 2000s the relative importance of the agricultural sector the overall economy has declined. In 2016, agriculture accounted for.0179 of GDP compared with.3548 and.6262, respectively, for industry and services. High-tech manufacturing employment accounted for an increasing proportion of total employment in the second half of the last decade. The services sector is clearly the most important sector in terms of employment and capital in 2016.

Table 4 illustrates changes in the relative contributions of the "Intangible Investments, Professional Technique Trades and Product Innovation or Technique Upgrade of Enterprise Units in All Industries in Taiwan, end of 2011". The grand total of proportion to operating revenues (\%) of production innovation, technology upgrade is 11.10 . By transactions of professional techniques, the 4 priority items in the amount of oversea purchasing (NT\$1,000) are follows: Manufacturing $(161,251,490)$, Wholesale and Retail Trade $(3,689,027)$, Information and Communication $(2,843,994)$, Professional, Scientific and Technical Activities $(349,304)$; the 4 priority items in the amount of oversea selling (NT\$1,000) are follows: Manufacturing $(14,095,086)$, Information and Communication $(1,001,420)$, Professional, Scientific and Technical Activities $(789,393)$, Wholesale and Retail Trade $(710,157)$. Table 5 illustrates changes in the relative contributions of the "Self-Branding Operations and Utilized/Expedited Dispatched Laborers of Enterprise Units in All Industries in Taiwan, end of 2011". By self-branding operations, the 4 priority items in the number of enterprise units are follows: Wholesale and Retail Trade $(17,400)$, Manufacturing $(13,797)$, Information and Communication $(1,975)$, Professional, Scientific and Technical Activities $(1,464)$. By Dispatched labors utilizing, the 4 priority items of the expenses of dispatched labors utilized $(\mathrm{NT} \$ 1,000)$ are 
follows: Manufacturing $(17,598,698)$, Wholesale and Retail

Compulsory Social Security Activities

$(2,948,115)$ Trade (4,104,104), Financial \& Insurance Activities,

Information and Communication $(2,708,157)$.

Table 4. Intangible Investments, Professional Technique Trades and Product Innovation or Technique Upgrade of Enterprise Units in All Industries in Taiwan, End of 2011.

\begin{tabular}{|c|c|c|c|c|c|c|c|}
\hline & \multirow{3}{*}{$\begin{array}{l}\text { Outline of Intangible } \\
\text { Investments } \\
\text { Research and } \\
\text { Development } \\
\begin{array}{l}\text { Number of enterprise } \\
\text { units (Enterprise) }\end{array} \\
\end{array}$} & \multicolumn{4}{|c|}{ Transactions of professional techniques } & \multicolumn{2}{|c|}{$\begin{array}{l}\text { Prod innovation, technology } \\
\text { upgrade }\end{array}$} \\
\hline & & \multicolumn{2}{|c|}{ Amount of purchasing } & \multicolumn{2}{|c|}{ Amount of selling } & \multirow{2}{*}{$\begin{array}{l}\text { Amount of } \\
\text { selling }\end{array}$} & \multirow{2}{*}{$\begin{array}{l}\text { Proportion to } \\
\text { operating } \\
\text { revenues }(\%)\end{array}$} \\
\hline & & domestic & oversea & domestic & oversea & & \\
\hline Grand Total & 19136 & 11505675 & 169465108 & 19334194 & 16628945 & 6124686198 & 11.10 \\
\hline Mining and Quarrying & 7 & - & - & - & - & - & - \\
\hline Electricity and Gas Supply & 16 & - & 172104 & - & 2135 & - & - \\
\hline $\begin{array}{l}\text { Water Supply and Remediation } \\
\text { Activities }\end{array}$ & 82 & 4180 & 12965 & - & - & - & - \\
\hline Construction & 427 & 405434 & 626639 & 116702 & 17092 & - & - \\
\hline Wholesale and Retail Trade & 3850 & 2696619 & 3689027 & 2789212 & 710157 & - & - \\
\hline Transportation and Storage & 182 & 77348 & 58976 & 314101 & 749 & - & - \\
\hline $\begin{array}{l}\text { Accommodation and Food Service } \\
\text { Activities }\end{array}$ & 213 & 32304 & 175016 & 24517 & 2107 & - & - \\
\hline Information and Communication & 863 & 1510282 & 2843994 & 3195151 & 1001420 & - & - \\
\hline $\begin{array}{l}\text { Financial \& Insurance Activities; } \\
\text { Compulsory Social Security } \\
\text { Activities }\end{array}$ & 289 & 216269 & 235847 & 851 & - & - & - \\
\hline Real Estate Activities & 157 & 896 & 30956 & - & - & - & - \\
\hline $\begin{array}{l}\text { Professional, Scientific and } \\
\text { Technical Activities }\end{array}$ & 546 & 451338 & 349304 & 7240987 & 789393 & - & - \\
\hline Support Service Activities & 140 & 188729 & 3734 & 1361 & 10806 & - & - \\
\hline Education & 359 & - & - & - & - & - & - \\
\hline $\begin{array}{l}\text { Human Health and Social Work } \\
\text { Activities }\end{array}$ & 987 & 316 & 9436 & 2671 & - & - & - \\
\hline Arts, Entertainment and Recreation & 124 & - & - & 8439 & - & - & - \\
\hline Other Service Activities & 382 & 10609 & 5620 & 101 & - & - & - \\
\hline
\end{tabular}

Source: Directorate General of Budget, Accounting and Statistics (DGBAS) of Executive Yuan, R. O. C. (Taiwan)

Unit: NT\$1,000

Notice: "-" means "No such item".

Table 5. Self-Branding Operations and Utilized/Expedited Dispatched Laborers of Enterprise Units in All Industries in Taiwan, End of 2011.

\begin{tabular}{|c|c|c|c|}
\hline & \multirow{2}{*}{$\begin{array}{l}\text { Number of enterprise } \\
\text { units (Enterprise) }\end{array}$} & \multicolumn{2}{|l|}{ Self-Branding Operations } \\
\hline & & $\begin{array}{l}\text { Number of enterprise } \\
\text { units (Enterprise) }\end{array}$ & $\begin{array}{l}\text { Revenues of self- branded } \\
\text { products sold oversea (NT\$1,000) }\end{array}$ \\
\hline Grand Total & 1184811 & 39663 & 3912230334 \\
\hline Mining and Quarrying & 431 & 1 & - \\
\hline Manufacturing & 157284 & 13797 & 3580387256 \\
\hline Electricity and Gas Supply & 171 & 3 & - \\
\hline Water Supply and Remediation Activities & 4965 & 1 & - \\
\hline Wholesale and Retail Trade & 495700 & 17400 & 331843078 \\
\hline Transportation and Storage & 54614 & 462 & - \\
\hline Accommodation and Food Service Activities & 112364 & 1254 & - \\
\hline Information and Communication & 13165 & 1975 & - \\
\hline $\begin{array}{l}\text { Financial \& Insurance Activities; Compulsory Social Security } \\
\text { Activities }\end{array}$ & 13806 & 793 & - \\
\hline Real Estate Activities & 20313 & 551 & - \\
\hline Education & 17369 & 451 & - \\
\hline Human Health and Social Work Activities & 29342 & 228 & - \\
\hline Arts, Entertainment and Recreation & 17084 & 136 & - \\
\hline Other Service Activities & 92655 & 332 & - \\
\hline
\end{tabular}


Table 5. Continued.

\begin{tabular}{|c|c|c|c|c|}
\hline & \multirow{2}{*}{$\begin{array}{l}\text { Number of } \\
\text { enterprise units } \\
\text { (Enterprise) }\end{array}$} & \multicolumn{3}{|l|}{ Dispatched labors utilizing } \\
\hline & & $\begin{array}{l}\text { Number of enterprise } \\
\text { units utilizing dispatched } \\
\text { labors (Enterprise) }\end{array}$ & $\begin{array}{l}\text { Average number of dispatched } \\
\text { labors utilized in enterprise } \\
\text { units, each month (Person) }\end{array}$ & $\begin{array}{l}\text { Expenses of dispatched labors } \\
\text { utilized, year-round of } 2011 \\
\text { (NT\$1,000) }\end{array}$ \\
\hline Grand Total & 1184811 & 7428 & 131296 & 35094581 \\
\hline Mining and Quarrying & 431 & 7 & 18 & 2469 \\
\hline Manufacturing & 157284 & 2529 & 63934 & 17598698 \\
\hline Electricity and Gas Supply & 171 & 9 & 1017 & 1167162 \\
\hline $\begin{array}{l}\text { Water Supply and } \\
\text { Remediation Activities }\end{array}$ & 4965 & 50 & 273 & 53965 \\
\hline Construction & 86350 & 1012 & 9553 & 1160912 \\
\hline Wholesale and Retail Trade & 495700 & 1854 & 16026 & 4104104 \\
\hline Transportation and Storage & 54614 & 206 & 9587 & 2343974 \\
\hline $\begin{array}{l}\text { Accommodation and Food } \\
\text { Service Activities }\end{array}$ & 112364 & 147 & 1566 & 294735 \\
\hline $\begin{array}{l}\text { Information and } \\
\text { Communication } \\
\text { Financial \& Insurance }\end{array}$ & 13165 & 221 & 7770 & 2708157 \\
\hline $\begin{array}{l}\text { Activities; Compulsory } \\
\text { Social Security Activities }\end{array}$ & 13806 & 222 & 9106 & 2948115 \\
\hline Real Estate Activities & & 122 & 858 & 138393 \\
\hline $\begin{array}{l}\text { Professional, Scientific and } \\
\text { Technical Activities }\end{array}$ & & 267 & 1892 & 490718 \\
\hline Support Service Activities & & 243 & 4582 & 770903 \\
\hline Education & & 104 & 350 & 50179 \\
\hline $\begin{array}{l}\text { Human Health and Social } \\
\text { Work Activities }\end{array}$ & & 220 & 3327 & 943980 \\
\hline $\begin{array}{l}\text { Arts, Entertainment and } \\
\text { Recreation }\end{array}$ & & 69 & 772 & 250126 \\
\hline Other Service Activities & & 146 & 665 & 67991 \\
\hline
\end{tabular}

Source: Directorate General of Budget, Accounting and Statistics (DGBAS) of Executive Yuan, R. O. C. (Taiwan)

Unit: Enterprise, NT\$1,000, Person

Notice: "-" means "No such item".

Table 6 illustrates changes in the relative contributions of the "Services or Labors Transacted across Borders, Direct Investments from Oversea and Personnel Activities across Borders of Enterprise Units in All Industries in Taiwan, end of 2011". By services or labors transacted across border, the 4 priority items in the number of enterprise units are follows: Wholesale and Retail Trade (13,712), Manufacturing $(7,463)$, Information and Communication (1,317), Professional, Scientific and Technical Activities $(1,254)$. By " $>=10 \%$ of enterprise equity held by single foreign shareholder", the 4 priority items in the number of enterprise units are follows: Wholesale and Retail Trade $(3,620)$, Manufacturing (1,498), Professional, Scientific and Technical Activities (684), Information and Communication (542). By personnel active across border, the 4 priority items of Domestic personnels go overseas for business reasons (enterprise) are follows: Wholesale and Retail Trade $(15,391)$, Manufacturing $(10,623)$, Professional, Scientific and Technical Activities (1,732), Information and Communication $(1,382)$; the 5 priority items of foreign personnels come in for business reasons (enterprise) are also follows: Wholesale and Retail Trade (4,140), Manufacturing $(3,691)$, Education (978), Professional, Scientific and Technical Activities (589), Information and Communication (458). Table 7 illustrates changes in the relative contributions of the "Foreign Branches of Enterprise Units in All Industries in Taiwan, end of 2011". With foreign branches established, the 5 priority items in the number of foreign branches established (enterprise) are follows: Wholesale and Retail Trade (1,733), Manufacturing (1,525), Financial \& Insurance Activities; Compulsory Social Security Activities (298), Transportation and Storage (266), Professional, Scientific and Technical Activities (205); the priority items of the Regional distribution in percentage are follows: China (incl. Hong Kong and Macau) (58.00), Asia (excl. China) (22.43), America (8.40), Others (7.51), Europe (3.66). 
Table 6. Services or Labors Transacted across Borders, Direct Investments from Oversea and Personnel Activities across Borders of Enterprise Units in All Industries in Taiwan, End of 2011.

\begin{tabular}{llll}
\hline & Number of enterprise & $\begin{array}{l}\text { Services or labors } \\
\text { Transacted across border }\end{array}$ & $\begin{array}{l}\text { >=10\% of enterprise equity held by } \\
\text { single foreign shareholder }\end{array}$ \\
\cline { 3 - 4 } & units (Enterprise) & $\begin{array}{l}\text { Number of enterprise } \\
\text { units (Enterprise) }\end{array}$ & $\begin{array}{l}\text { Number of enterprise units } \\
\text { (Enterprise) }\end{array}$ \\
\hline Grand Total & 1184811 & 27268 & 8073 \\
Mining and Quarrying & 431 & 7 & - \\
Manufacturing & 157284 & 7463 & 1498 \\
Electricity and Gas Supply & 171 & 11 & 9 \\
Water Supply and Remediation Activities & 4965 & 48 & 15 \\
Construction & 86350 & 811 & 170 \\
Wholesale and Retail Trade & 495700 & 13712 & 3620 \\
Transportation and Storage & 54614 & 694 & 284 \\
Accommodation and Food Service Activities & 112364 & 162 & 109 \\
Information and Communication & 13165 & 1317 & 542 \\
Financial \& Insurance Activities; Compulsory Social & 13806 & 334 & 507 \\
Security Activities & 20313 & 152 & 204 \\
Real Estate Activities & 47591 & 1254 & 684 \\
Professional, Scientific and Technical Activities & 21607 & 878 & 298 \\
Support Service Activities & 17369 & 129 & 40 \\
Education & 29342 & 85 & 22 \\
Human Health and Social Work Activities & 17084 & 91 & 32 \\
Arts, Entertainment and Recreation & 92655 & 120 & 39 \\
Other Service Activities & & & \\
\hline
\end{tabular}

Table 6. Continued.

\begin{tabular}{|c|c|c|c|c|}
\hline & \multirow{2}{*}{$\begin{array}{l}\text { Number of } \\
\text { enterprise units } \\
\text { (Enterprise) }\end{array}$} & \multicolumn{3}{|c|}{ Personnel active across border } \\
\hline & & $\begin{array}{l}\text { Number of enterprise } \\
\text { units (Enterprise) }\end{array}$ & $\begin{array}{l}\text { Domestic personnels go overseas } \\
\text { for business reasons (Enterprise) }\end{array}$ & $\begin{array}{l}\text { Foreign personnels come in for } \\
\text { business reasons (Enterprise) }\end{array}$ \\
\hline Grand Total & 1184811 & 37768 & 34465 & 11915 \\
\hline Mining and Quarrying & 431 & 8 & 5 & 3 \\
\hline Manufacturing & 157284 & 11298 & 10623 & 3691 \\
\hline Electricity and Gas Supply & 171 & 18 & 14 & 11 \\
\hline $\begin{array}{l}\text { Water Supply and } \\
\text { Remediation Activities }\end{array}$ & 4965 & 75 & 70 & 14 \\
\hline Construction & 86350 & 1536 & 1435 & 324 \\
\hline Wholesale and Retail Trade & 495700 & 16103 & 15391 & 4140 \\
\hline Transportation and Storage & 54614 & 611 & 570 & 234 \\
\hline $\begin{array}{l}\text { Accommodation and Food } \\
\text { Service Activities }\end{array}$ & 112364 & 352 & 281 & 148 \\
\hline $\begin{array}{l}\text { Information and } \\
\text { Communication } \\
\text { Financial \& Insurance }\end{array}$ & 13165 & 1482 & 1382 & 458 \\
\hline $\begin{array}{l}\text { Activities; Compulsory } \\
\text { Social Security Activities }\end{array}$ & 13806 & 866 & 660 & 437 \\
\hline Real Estate Activities & 20313 & 371 & 350 & 74 \\
\hline $\begin{array}{l}\text { Professional, Scientific and } \\
\text { Technical Activities }\end{array}$ & 47591 & 1853 & 1732 & 589 \\
\hline Support Service Activities & 21607 & 1140 & 1056 & 398 \\
\hline Education & 17369 & 1115 & 196 & 978 \\
\hline $\begin{array}{l}\text { Human Health and Social } \\
\text { Work Activities }\end{array}$ & 29342 & 521 & 340 & 270 \\
\hline $\begin{array}{l}\text { Arts, Entertainment and } \\
\text { Recreation }\end{array}$ & 17084 & 169 & 148 & 73 \\
\hline Other Service Activities & 92655 & 250 & 212 & 73 \\
\hline
\end{tabular}

Source: Directorate General of Budget, Accounting and Statistics (DGBAS) of Executive Yuan, R. O. C. (Taiwan)

Unit: Enterprise

Notice: "-" means "No such item". 
Table 7. Foreign Branches of Enterprise Units in All Industries in Taiwan, End of 2011.

\begin{tabular}{|c|c|c|c|c|c|c|c|c|}
\hline & \multirow{3}{*}{$\begin{array}{l}\text { Number of } \\
\text { enterprise units } \\
\text { (Enterprise) }\end{array}$} & \multicolumn{7}{|c|}{ With foreign branches established, end of 2011} \\
\hline & & \multirow{2}{*}{$\begin{array}{l}\begin{array}{l}\text { Number of } \\
\text { enterprise units } \\
\text { (Enterprise) }\end{array} \\
\end{array}$} & \multirow{2}{*}{$\begin{array}{l}\text { Number of foreign } \\
\text { branches established } \\
\text { (Enterprise) }\end{array}$} & \multicolumn{5}{|c|}{ Regional distribution in percentage } \\
\hline & & & & $\begin{array}{l}\text { China (incl. Hong } \\
\text { Kong and Macau) }\end{array}$ & $\begin{array}{l}\text { Asia (excl. } \\
\text { China) }\end{array}$ & America & Europe & Others \\
\hline Grand Total & 1184811 & 2123 & 4512 & 58.00 & 22.43 & 8.40 & 3.66 & 7.51 \\
\hline Mining and Quarrying & 431 & - & - & - & - & - & - & - \\
\hline Manufacturing & 157284 & 777 & 1525 & 56.26 & 20.33 & 8.26 & 5.97 & 9.18 \\
\hline $\begin{array}{l}\text { Electricity and Gas } \\
\text { Supply }\end{array}$ & 171 & 2 & 2 & - & - & - & - & 100.00 \\
\hline $\begin{array}{l}\text { Water Supply and } \\
\text { Remediation Activities }\end{array}$ & 4965 & 2 & 2 & 50.00 & 50.00 & - & - & - \\
\hline Construction & 86350 & 67 & 102 & 41.18 & 56.86 & - & 0.98 & 0.98 \\
\hline $\begin{array}{l}\text { Wholesale and Retail } \\
\text { Trade }\end{array}$ & 495700 & 884 & 1733 & 71.26 & 18.23 & 4.10 & 0.35 & 6.06 \\
\hline $\begin{array}{l}\text { Transportation and } \\
\text { Storage }\end{array}$ & 54614 & 49 & 266 & 57.52 & 24.44 & 7.52 & 4.51 & 6.02 \\
\hline $\begin{array}{l}\text { Accommodation and } \\
\text { Food Service Activities }\end{array}$ & 112364 & 20 & 43 & - & 100.00 & - & - & - \\
\hline $\begin{array}{l}\text { Information and } \\
\text { Communication }\end{array}$ & 13165 & 96 & 186 & 47.31 & 17.20 & 6.99 & 5.91 & 22.58 \\
\hline $\begin{array}{l}\text { Financial \& Insurance } \\
\text { Activities; Compulsory } \\
\text { Social Security } \\
\text { Activities }\end{array}$ & 13806 & 73 & 298 & 28.52 & 33.22 & 19.46 & 10.74 & 8.05 \\
\hline $\begin{array}{l}\text { Real Estate Activities } \\
\text { Professional, Scientific }\end{array}$ & 20313 & 11 & 12 & 58.33 & 41.67 & - & - & - \\
\hline $\begin{array}{l}\text { and Technical } \\
\text { Activities }\end{array}$ & 47591 & 76 & 205 & 52.68 & 18.54 & 26.83 & 0.49 & 1.46 \\
\hline $\begin{array}{l}\text { Support Service } \\
\text { Activities }\end{array}$ & 21607 & 45 & 104 & 23.08 & 40.38 & 21.15 & 10.58 & 4.81 \\
\hline Education & 17369 & 6 & 14 & 42.86 & - & 57.14 & - & - \\
\hline $\begin{array}{l}\text { Human Health and } \\
\text { Social Work Activities }\end{array}$ & 29342 & 2 & 2 & - & - & 50.00 & - & 50.00 \\
\hline $\begin{array}{l}\text { Arts, Entertainment and } \\
\text { Recreation }\end{array}$ & 17084 & 6 & 8 & 87.50 & - & 12.50 & - & - \\
\hline $\begin{array}{l}\text { Other Service } \\
\text { Activities }\end{array}$ & 92655 & 7 & 10 & 30.00 & 30.00 & 40.00 & - & - \\
\hline
\end{tabular}

Source: Directorate General of Budget, Accounting and Statistics (DGBAS) of Executive Yuan, R. O. C. (Taiwan)

Unit: Enterprise, \%

Notice: "-" means "No such item".

Table 8 illustrates changes in the relative contributions of the "Development Status of Five New Emerging Industries and International Logistics Industry in Taiwan, end of 2011". By number of enterprise units (enterprise), the priority items are follows: Cultural creativity industry $(45,168)$, Health and nursing care industry $(26,969)$, International logistics industry $(14,277)$, Biotechnology industry $(3,515)$, Green energy industry $(1,687)$. By number of persons engaged (person), the priority items are follows: Health and nursing care industry $(408,009)$, Tourism industry $(276,799)$, Cultural creativity industry $(212,656)$, International logistics industry $(164,448)$, Green energy industry $(70,863)$, Biotechnology industry $(64,824)$. By total value of production (NT $\$ 1,000,000$ ), the priority items are follows: Health and nursing care industry $(781,267)$, International logistics industry $(755,304)$, Cultural creativity industry $(709,269)$, Tourism industry $(530,674)$, Green energy industry $(360,414)$, Biotechnology industry $(196,966)$.

Table 8. Development Status of Five New Emerging Industries and International Logistics Industry in Taiwan, End of 2011.

\begin{tabular}{llll}
\hline & $\begin{array}{l}\text { Number of enterprise units } \\
\text { (Enterprise) }\end{array}$ & Number of persons engaged (Person) & $\begin{array}{l}\text { Total value of production } \\
\text { (NT\$1,000,000) }\end{array}$ \\
\hline Green energy industry & 1687 & 70863 & 360414 \\
Biotechnology industry & 3515 & 64824 & 196966 \\
Cultural creativity industry & 45168 & 212656 & 709269 \\
Tourism industry & - & 276799 & 530674 \\
Health and nursing care industry & 26969 & 408009 & 781267 \\
International logistics industry & 14277 & 164448 & 755304 \\
\hline
\end{tabular}

Source: Directorate General of Budget, Accounting and Statistics (DGBAS) of Executive Yuan, R. O. C. (Taiwan)

Unit: Enterprise, Person, NT\$1,000,000 
The amended statute for industrial innovation was approved by the Legislature November 3, 2017. The amendments consists of four components: promoting innovation, strengthening $\mathrm{R} \& \mathrm{D}$, guiding innovation, and revitalizing the environment. Innovation policy had long been anchored in a type of technology-push policy. Industrial parks were built by the government and had the goal of fostering industrial location as a highway for economic growth and job creation. These technological parks are intended to be connected to the dynamic sectors of the third industrial revolution: electronics, computers, new materials, telecommunications, and later biotechnology. The government plays a key role in facilitating economic growth through its investment in infrastructure and stimulation of capacity development and mass production to ensure full employment. One important policy instrument has been restructuring programmes that guide firms from mass production to flexible specialization. Companies have to constantly develop cutting-edge products and processes to maintain a competitive edge in a global economy. This necessity to innovate and to find new sources of knowledge is reflected in the increasing internationalization of R\&D activities. Local governments, workers and consumers welcome foreign investments, new knowledge and opportunities. Foreign firms are tapping into localized knowledge clusters to augment their competitive advantage. Major labor market reforms in Taiwan are essential to spur job creation, lower unemployment, and help prevent further sliding into cycles of long-term deterioration of output growth. The innovative performances such as ICT is connected to the flexibility of its labor markets, which promote diversity in the enterprise knowledge base. Industrial policies emphasize strengthening the capabilities of firms and developing their skills, knowledge, and networking abilities. Innovation policy had long been anchored in a type of technology-push policy. Taiwan has become the world's leading producer and exporter of value-added creative products. Taiwan views creativity as vital to the economy to an innovationdriven global economy.

By 2009 Taiwan's unemployment rate was 5.85 per cent, which is shown in Table 9. These slightly improved unemployment rates understate the extent of hardship experienced by young people as a result of the crisis. In the 2009 , youth (aged 15 to 24) unemployment had reached 14.49 per cent, compared with 5.93 per cent for the adults (aged 25-44 years). By 2009 Taiwan's labor force participation rate was 57.9 per cent, which is shown in Table 10. In 2009, youth (aged 15 to 24) accounted for 28.6 of labor force participation rate compared with 84.2 and 60.3, respectively, for the adults (aged 25-44 years) and the adults (aged 45-64 years) services. The major problem of the Taiwan labour market policies are the worryingly high level of unemployment and the development of atypical forms of employment. Young people are instead finding themselves without a job and potentially falling into longterm unemployment. This will raise crucial issues if it results in a process of increasing job insecurity and increasingly precarious living standards. Table 11 shows that the overall age structures of the population of Taiwan are far from being stationary. That economic landscape has now radically changed, with a complex web of production and supply links extending to manufacturing and services sectors, helped by rapid technological progress. While youth unemployed reached a record high, older workers, aged above 65 years, were badly affected, showing the big fall in that category since records began in 2010. The government is faced with a challenge to ensure that that there are enough working-age people to provide a labour force needed for new investment and growth and to fund the pension system. The outflows of some of the best and brightest workers from Taiwan to China Mainland continue to grow.

Table 9. Unemployment rate in Taiwan, End of 1998-2013.

\begin{tabular}{|c|c|c|c|c|c|c|c|c|}
\hline \multirow[b]{2}{*}{ Year } & \multirow{2}{*}{$\begin{array}{l}\text { Total } \\
(\%)\end{array}$} & \multicolumn{4}{|l|}{ age } & \multicolumn{3}{|c|}{ educational level } \\
\hline & & $\begin{array}{l}15-24 \text { years } \\
(\%)\end{array}$ & $\begin{array}{l}\text { 25-44 years } \\
(\%)\end{array}$ & $\begin{array}{l}\text { 45-64 years } \\
(\%)\end{array}$ & $\begin{array}{l}65 \text { years and } \\
\text { over }(\%)\end{array}$ & $\begin{array}{l}\text { Junior high \& } \\
\text { below (\%) }\end{array}$ & $\begin{array}{l}\text { Senior high \& } \\
\text { vocational }(\%)\end{array}$ & $\begin{array}{l}\text { Junior college \& } \\
\text { above }(\%)\end{array}$ \\
\hline 1998 & 2.69 & 7.32 & 2.26 & 1.44 & 0.19 & 2.28 & 3.09 & 2.80 \\
\hline 2009 & 5.85 & 14.49 & 5.93 & 3.90 & 0.13 & 5.84 & 6.19 & 5.57 \\
\hline 2010 & 5.21 & 13.09 & 5.35 & 3.39 & 0.19 & 4.83 & 5.58 & 5.12 \\
\hline 2013 & 4.18 & 13.17 & 4.27 & 2.25 & 0.14 & 3.53 & 4.11 & 4.50 \\
\hline
\end{tabular}

Source: Directorate General of Budget, Accounting and Statistics (DGBAS) of Executive Yuan, R. O. C. (Taiwan)

Table 10. Labor force participation rate in Taiwan, End of 1998-2013.

\begin{tabular}{lllllll}
\hline Year & Total $(\%)$ & $\mathbf{1 5 - 2 4}$ years $(\%)$ & $\mathbf{2 5 - 4 4}$ years $(\boldsymbol{\%})$ & $\mathbf{4 5 - 6 4}$ years $(\%)$ & 65 years and over $(\%)$ & foreign workers in Taiwan $(\mathbf{1 , 0 0 0 )}$ \\
\hline 1998 & 58.0 & 36.0 & 79.2 & 60.8 & 8.5 & 271 \\
2009 & 57.9 & 28.6 & 84.2 & 60.3 & 8.1 & 351 \\
2010 & 58.1 & 28.8 & 84.7 & 60.3 & 8.1 & 380 \\
2013 & 58.4 & 29.6 & 86.6 & 60.7 & 8.3 & 489 \\
\hline
\end{tabular}

Source: Directorate General of Budget, Accounting and Statistics (DGBAS) of Executive Yuan, R. O. C. (Taiwan) 
Table 11. Population in Taiwan, End of 1998-2061.

\begin{tabular}{llllll}
\hline \multirow{2}{*}{ Year } & Population Composition & \multicolumn{3}{l}{} \\
\cline { 2 - 6 } & $\begin{array}{l}\text { Percentage of population } \\
\text { aged 0-14 (\%) }\end{array}$ & $\begin{array}{l}\text { Percentage of population } \\
\text { aged 15-64 (\%) }\end{array}$ & $\begin{array}{l}\text { Percentage of population aged } \\
\mathbf{6 5} \text { and over (\%) }\end{array}$ & Dependent ratio (\%) & Index of ageing (\%) \\
\hline 1998 & 22.0 & 69.8 & 8.3 & 43.3 & 37.6 \\
2010 & 15.6 & 73.6 & 10.7 & 35.8 & 68.6 \\
2013 & 14.3 & 74.2 & 11.5 & 34.9 & - \\
2014 & - & - & - & - & - \\
2017 & - & - & - & - & - \\
2020 & - & - & - & - & - \\
2023 & - & - & - & - & - \\
2026 & - & - & - & - & - \\
2029 & - & - & - & - & - \\
2032 & - & - & - & - & - \\
2035 & - & - & - & - & - \\
2038 & - & - & - & - & - \\
2041 & - & - & - & - & - \\
2044 & - & - & - & - & - \\
2047 & - & - & - & - & - \\
2050 & - & - & - & - & - \\
2053 & - & - & - & - & - \\
2056 & - & - & - & - & - \\
2061 & - & - & - & - & - \\
\hline
\end{tabular}

Table 11. Continued.

\begin{tabular}{llllll}
\hline & Population annual & Population Projections & & & \\
\cline { 4 - 5 } Year & Total population (1,000) & Population aged 0-14 (1,000) & Population aged 15-64 (1,000) & $\begin{array}{l}\text { Population aged 65 and } \\
\text { over (1,000) }\end{array}$ \\
\hline 1998 & 8.5 & - & - & - & - \\
2010 & 1.8 & - & - & - & - \\
2013 & 2.5 & - & - & - & - \\
2014 & - & 23419 & 3260 & 17347 & 2812 \\
2017 & - & 23517 & 3020 & 17218 & 3279 \\
2020 & - & 23559 & 2909 & 16846 & 3804 \\
2023 & - & 23552 & 2825 & 16378 & 4348 \\
2026 & - & 23497 & 15810 & 4910 \\
2029 & - & 23382 & 2647 & 5452 \\
2032 & - & 23192 & 2440 & 15286 & 5901 \\
2035 & - & 22917 & 2317 & 14745 & 6297 \\
2038 & - & 22554 & 2178 & 13650 & 6588 \\
2041 & - & 22111 & 2038 & 13057 & 6876 \\
2044 & - & 21601 & 1912 & 12387 & 7176 \\
2047 & - & 21031 & 1805 & 11682 & 7437 \\
2050 & - & 20414 & 1720 & 11070 & 7539 \\
2053 & - & 19766 & 1652 & 10551 & 7495 \\
2056 & - & 19097 & 1556 & 9000 & 745 \\
2061 & - & 17952 & 9040 & 7356 \\
\hline
\end{tabular}

Source: Directorate General of Budget, Accounting and Statistics (DGBAS) of Executive Yuan, R. O. C. (Taiwan)

Notice: "-" means "No such item".

Population ageing is the important feature of the forecasted population change. In 2013, aged 0-14 (\%) accounted for 14.3 of population composition compared with 74.2 and 11.5 , respectively, for aged 15-64 (\%) and aged 65 and over (\%). The dependent ratio (\%) decreases from 43.3 in 1998 , to 35.8 in 2010, and to 34.9 in 2013 . The changes are even more visible in the development of the population projections. Between 2014 and 2061, the population will shrink by almost $25 \%$, from 23.419 million to 17.952 million people. The difficult situation of Taiwan is a result of a combination of two independent factors: low fertility levels and low labour force participation rates. The labour force aging problem is especially troublesome in the labour market, where unemployment is high. This approach to modelling population of Taiwan was triggered by the factors: massive international migration flows have changed the dynamics of national populations and, some decision makers considered international migration as a remedy for population aging. These changes will decrease the proportions of middle age groups. Between 2014 and 2061, population aged 65 and over is expected increase by $262 \%$ (from 2.812 million people in 2014 to 7.356 in 2061). The share of the population aged 15-64 is envisaged to decrease by $50 \%$ (from 17.347 million people in 2014 to 9.040 in 2061). Such changes will require significant adjustments of labour markets in order to meet the needs of an increasing number of elderly workers. 
Without immigrants from the other parts of the world, the labour force resources in Taiwan would not complete the gaps for the ageing. The demand for a highly educated workforce associated with Taiwan's growing knowledge economy has led to the increasing recruitment of skilled immigrants. To overcome Taiwan's technical talent shortage while supporting national policies, the government drafted the Act for the "Recruitment and Employment of Foreign Professionals" after a thorough examination of the difficulties and barriers encountered by foreign professionals seeking to work and live in Taiwan. This special law was passed on October 31, 2017, marking a major milestone in Taiwan's recruitment and retention efforts. Taiwan has an immigration system for recruiting immigrants based on skills and human capital using various programs under the economic immigration stream. A new law for knowledge migrants allowed highly skilled workers with job offers for a minimum of years to obtain a residence permit. The government brought about a remarkable shift in the Taiwan's migration policy towards more openness for labour migration. The Taiwan migration policy stemmed from the recognition of labour shortages in some sectors and as demographic concerns, and made a remarkable shift towards more openness based on economic needs assessment.

Taiwan has ranked 23rd among 63 countries in the IMD World Talent Report 2017. Despite its decent ranking, the report is an indication that Taiwan should be aware of its diminishing talent pool. Taiwan is placed at 23, the same ranking as last year after adjustments, but lags behind Hong Kong (12) and Singapore (13) while staying ahead of Malaysia (28) and Japan (31) among Asian countries. In the category of investment and development, Taiwan enterprises are noted to value employee training, but total public expenditure on education as well as Taiwan's pupil-teacher ratio in secondary education, are in inferior positions. Taiwan performs fairly well on effective personal income tax rate, but exhibits inconsistent performance on indicators like the cost-of-living index, brain drain and foreign highly-skilled personnel. The situation might become worse if Taiwanese professional talent continues to move out of the country, and if no foreign highly-skilled professionals arrive to balance their absence, which will further diminish an already drained talent pool. The economies that perform the best in the evaluation share similar aspects of attractiveness, including high investment on education systems from primary to tertiary levels, substantial opportunities for career advancement and a superior life quality.

Taiwan has largely benefited from the transition from an agricultural to an industrial to post-industrial economy. Table 12 shows the percentage share of disposable income by quintile group of households and income inequality indices in Taiwan, as measured by the Gini Index (the statistical measure of income equality). The Gini's concentration coefficien slighted increased from 0.321 in 1964 to 0.336 in 2016. It shows a stable proportion of the population practising high mobility across age groups. Table 13 shows the income distribution in selected countries (or local communities), such as Singapore, Hong Kong, Japan, China, France, Germany, Italy, UK and USA. Taiwan made efforts in the changes of disposable income occurred by current transfers between households and government. Taiwan wants to achieve the kind of mobility that maximizes the development and returns on human capital that are important to spurring economic growth. The achievement of educational systems that bridge the socioeconomic gap between origin and destination still has a very long way to go. Access to education plays a role in upward intergenerational social mobility. Lack of appropriate level of education to perform advanced technology-required jobs caused some workers to experience downward mobility by taking lower-paying jobs. Table 14 shows the mean disposable income of income recipients by educational attainment in Taiwan. In 2016, graduate school and above accounted for -3.08 of change (\%) compared with 1.34 and 0.58 , respectively, for university and "primary school, supplementary school and illiteracy services". Access to higher education may contribute to increase opportunities for upward social mobility. But in a difficult economic climate with increasing job insecurity, social mobility is declining in Taiwan. Employable graduates take years to become financially independent from their families, and they become frustrated and pessimistic about the future. Not only does society lose the talents, skills, and energy of a host of otherwise high-performing young people, the result is economically disastrous.

Table 12. Percentage Share of Disposable Income by Quintile Group of Households and Income Inequality Indices in Taiwan, End of $1964-2016$.

\begin{tabular}{|c|c|c|c|c|c|c|c|}
\hline \multirow{2}{*}{ Year } & \multicolumn{5}{|c|}{ Percent distribution of disposable income by quintile of households } & \multirow{2}{*}{$\begin{array}{l}\text { Ratio of income share of highest } \\
20 \% \text { to that of lowest } 20 \%\end{array}$} & \multirow{2}{*}{$\begin{array}{l}\text { Gini's concentration } \\
\text { coefficient }\end{array}$} \\
\hline & Lowest $20 \%$ & Second $20 \%$ & Third $20 \%$ & Fourth $20 \%$ & Highest $20 \%$ & & \\
\hline 1964 & 7.71 & 12.57 & 16.62 & 22.03 & 41.07 & 5.33 & 0.321 \\
\hline 1970 & 8.44 & 13.27 & 17.09 & 22.51 & 38.69 & 4.58 & 0.294 \\
\hline 1972 & 8.60 & 13.25 & 17.06 & 22.48 & 38.61 & 4.49 & 0.291 \\
\hline 1974 & 8.84 & 13.49 & 16.99 & 22.05 & 38.63 & 4.37 & 0.287 \\
\hline 1976 & 8.91 & 13.64 & 17.48 & 22.71 & 37.26 & 4.18 & 0.280 \\
\hline 1977 & 8.96 & 13.48 & 17.31 & 22.57 & 37.68 & 4.21 & 0.284 \\
\hline 1978 & 8.89 & 13.71 & 17.53 & 22.70 & 37.17 & 4.18 & 0.287 \\
\hline 1979 & 8.64 & 13.68 & 17.48 & 22.68 & 37.52 & 4.34 & 0.285 \\
\hline 1980 & 8.82 & 13.90 & 17.70 & 22.78 & 36.80 & 4.17 & 0.278 \\
\hline 1981 & 8.80 & 13.76 & 17.62 & 22.78 & 37.04 & 4.21 & 0.281 \\
\hline 1982 & 8.69 & 13.80 & 17.56 & 22.69 & 37.26 & 4.29 & 0.283 \\
\hline 1983 & 8.61 & 13.64 & 17.47 & 22.73 & 37.54 & 4.36 & 0.287 \\
\hline 1984 & 8.49 & 13.69 & 17.62 & 22.83 & 37.36 & 4.40 & 0.287 \\
\hline
\end{tabular}




\begin{tabular}{|c|c|c|c|c|c|c|c|}
\hline \multirow{2}{*}{ Year } & \multicolumn{5}{|c|}{ Percent distribution of disposable income by quintile of households } & \multirow{2}{*}{$\begin{array}{l}\text { Ratio of income share of highest } \\
20 \% \text { to that of lowest } 20 \%\end{array}$} & \multirow{2}{*}{$\begin{array}{l}\text { Gini's concentration } \\
\text { coefficient }\end{array}$} \\
\hline & Lowest 20\% & Second $20 \%$ & Third 20\% & Fourth 20\% & Highest $20 \%$ & & \\
\hline 1985 & 8.37 & 13.59 & 17.52 & 22.88 & 37.64 & 4.50 & 0.291 \\
\hline 1986 & 8.30 & 13.51 & 17.38 & 22.65 & 38.16 & 4.60 & 0.296 \\
\hline 1987 & 8.11 & 13.50 & 17.53 & 22.82 & 38.04 & 4.69 & 0.299 \\
\hline 1988 & 7.89 & 13.43 & 17.55 & 22.88 & 38.25 & 4.85 & 0.303 \\
\hline 1989 & 7.70 & 13.50 & 17.72 & 23.07 & 38.01 & 4.94 & 0.303 \\
\hline 1990 & 7.45 & 13.22 & 17.51 & 23.22 & 38.60 & 5.18 & 0.312 \\
\hline 1991 & 7.76 & 13.26 & 17.42 & 22.97 & 38.60 & 4.97 & 0.308 \\
\hline 1992 & 7.37 & 13.24 & 17.52 & 23.21 & 38.66 & 5.24 & 0.312 \\
\hline 1993 & 7.13 & 13.12 & 17.65 & 23.44 & 38.66 & 5.43 & 0.315 \\
\hline 1994 & 7.28 & 12.97 & 17.41 & 23.18 & 39.17 & 5.38 & 0.318 \\
\hline 1995 & 7.30 & 12.96 & 17.37 & 23.38 & 38.99 & 5.34 & 0.317 \\
\hline 1996 & 7.22 & 13.00 & 17.50 & 23.38 & 38.89 & 5.38 & 0.317 \\
\hline 1997 & 7.24 & 12.91 & 17.46 & 23.25 & 39.14 & 5.41 & 0.320 \\
\hline 1998 & 7.12 & 12.84 & 17.53 & 23.24 & 39.26 & 5.51 & 0.324 \\
\hline 1999 & 7.13 & 12.91 & 17.51 & 23.21 & 39.24 & 5.50 & 0.325 \\
\hline 2000 & 7.07 & 12.82 & 17.47 & 23.41 & 39.23 & 5.55 & 0.326 \\
\hline 2001 & 6.43 & 12.08 & 17.04 & 23.33 & 41.11 & 6.39 & 0.350 \\
\hline 2002 & 6.67 & 12.30 & 16.99 & 22.95 & 41.09 & 6.16 & 0.345 \\
\hline 2003 & 6.72 & 12.37 & 16.91 & 23.17 & 40.83 & 6.07 & 0.343 \\
\hline 2004 & 6.67 & 12.46 & 17.41 & 23.25 & 40.21 & 6.03 & 0.338 \\
\hline 2005 & 6.66 & 12.43 & 17.42 & 23.32 & 40.17 & 6.04 & 0.340 \\
\hline 2006 & 6.66 & 12.37 & 17.42 & 23.51 & 40.03 & 6.01 & 0.339 \\
\hline 2007 & 6.76 & 12.36 & 17.31 & 23.16 & 40.41 & 5.98 & 0.340 \\
\hline 2008 & 6.64 & 12.37 & 17.43 & 23.40 & 40.17 & 6.05 & 0.341 \\
\hline 2009 & 6.36 & 12.27 & 17.39 & 23.64 & 40.34 & 6.34 & 0.345 \\
\hline 2010 & 6.49 & 12.21 & 17.39 & 23.72 & 40.19 & 6.19 & 0.342 \\
\hline 2011 & 6.53 & 12.05 & 17.32 & 23.86 & 40.25 & 6.17 & 0.342 \\
\hline 2012 & 6.53 & 12.27 & 17.54 & 23.68 & 39.98 & 6.13 & 0.338 \\
\hline 2013 & 6.57 & 12.38 & 17.49 & 23.60 & 39.96 & 6.08 & 0.336 \\
\hline 2014 & 6.63 & 12.28 & 17.36 & 23.59 & 40.13 & 6.05 & 0.336 \\
\hline 2015 & 6.64 & 12.18 & 17.35 & 23.63 & 40.21 & 6.06 & 0.338 \\
\hline 2016 & 6.63 & 12.42 & 17.35 & 23.24 & 40.36 & 6.08 & 0.336 \\
\hline
\end{tabular}

Source: Directorate General of Budget, Accounting and Statistics (DGBAS) of Executive Yuan, R. O. C. (Taiwan)

Table 13. Income Distribution in Selected Countries (or local communities).

\begin{tabular}{|c|c|c|c|c|c|}
\hline \multirow{2}{*}{$\begin{array}{l}\text { Countries (or local } \\
\text { communities) }\end{array}$} & \multirow[t]{2}{*}{ Year } & \multicolumn{2}{|c|}{$\begin{array}{l}\text { Quintile shares of total } \\
\text { income }(\%)\end{array}$} & \multirow{2}{*}{$\begin{array}{l}\text { Ratio of income share of highest } 20 \% \text { to that of } \\
\text { lowest } 20 \% \text { households }\end{array}$} & \multirow{2}{*}{$\begin{array}{l}\text { Gini's concentration } \\
\text { coefficient }\end{array}$} \\
\hline & & Lowest $20 \%$ & Highest $20 \%$ & & \\
\hline A. Per household & - & - & - & - & - \\
\hline Hong Kong & 2016 & - & - & 20.20 & 0.524 \\
\hline Japan (a) & 2016 & 6.6 & 41.8 & 6.31 & - \\
\hline Republic of China & 2016 & 6.6 & 40.4 & 6.08 & 0.336 \\
\hline U.S.A (a) & 2009 & 4.6 & 44.4 & 9.59 & 0.388 \\
\hline U.S.A (b) & 2015 & 3.1 & 51.1 & 16.25 & 0.479 \\
\hline B. Per capita & - & - & - & - & - \\
\hline Brazil & 2013 & 3.3 & 57.4 & 17.39 & 0.529 \\
\hline Canada & 2010 & 7.1 & 41.0 & 5.77 & 0.337 \\
\hline China & 2012 & 5.2 & 47.9 & 9.21 & 0.422 \\
\hline Colombia & 2013 & 3.4 & 58.0 & 17.06 & 0.535 \\
\hline Finland & 2012 & 9.4 & 36.7 & 3.90 & 0.271 \\
\hline France & 2012 & 7.8 & 41.2 & 5.28 & 0.331 \\
\hline Germany & 2011 & 8.4 & 38.6 & 4.60 & 0.301 \\
\hline Italy & 2012 & 6.2 & 41.7 & 6.73 & 0.352 \\
\hline Japan & 2009 & 7.9 & 39.2 & 4.99 & 0.310 \\
\hline Korea, Rep. & 2016 & - & - & 5.45 & 0.304 \\
\hline Luxembourg & 2012 & 7.1 & 41.9 & 5.90 & 0.348 \\
\hline Malaysia & 2009 & 4.6 & 51.4 & 11.17 & 0.463 \\
\hline Mexico & 2012 & 4.9 & 54.1 & 11.04 & 0.481 \\
\hline Netherlands & 2012 & 8.9 & 37.1 & 4.17 & 0.280 \\
\hline New Zealand & 1997 & 6.4 & 43.8 & 6.84 & 0.362 \\
\hline Norway & 2012 & 9.3 & 35.3 & 3.80 & 0.259 \\
\hline Republic of China & 2016 & 9.6 & 37.5 & 3.89 & 0.278 \\
\hline Singapore & 2016 & 4.4 & 50.8 & 11.66 & 0.458 \\
\hline Sweden & 2012 & 8.7 & 36.2 & 4.16 & 0.273 \\
\hline
\end{tabular}




\begin{tabular}{lllllll}
\hline \multirow{2}{*}{$\begin{array}{l}\text { Countries (or local } \\
\text { communities) }\end{array}$} & Year & \multicolumn{2}{l}{$\begin{array}{l}\text { Quintile shares of total } \\
\text { income (\%) }\end{array}$} & $\begin{array}{l}\text { Ratio of income share of highest 20\% to that of } \\
\text { lowest 20\% households }\end{array}$ & $\begin{array}{l}\text { Gini's concentration } \\
\text { coefficient }\end{array}$ \\
\cline { 2 - 5 } & Lowest 20\% & Highest 20\% & 0.390 \\
\hline United Kingdom & 2015 & 6.0 & 45.0 & 8.20 & 0.462 \\
\hline U.S.A & 2015 & 3.4 & 49.8 & 14.65 & \\
\hline
\end{tabular}

Source: Directorate General of Budget, Accounting and Statistics (DGBAS) of Executive Yuan, R. O. C. (Taiwan)

Notice: "“" means "No such item".

Table 14. Mean Disposable Income of Income Recipients by Educational Attainment in Taiwan, End of 2015-2016.

\begin{tabular}{lllll}
\hline & $\mathbf{2 0 1 5}$ & & $\mathbf{2 0 1 6}$ & \\
\cline { 2 - 5 } & Value (NT\$) & Change (\%) & Value (NT\$) & Change (\%) \\
\hline All income recipient & 525,285 & 0.07 & 532,864 & 1.44 \\
Education Attainment & & & \\
Graduate school and above & 935,478 & 2.73 & 906,699 & -3.08 \\
University & 604,308 & -0.74 & 612,400 & 1.34 \\
Junior college & 629,961 & -0.19 & 639,273 & 1.48 \\
Senior high school & 496,886 & -0.64 & 504,668 & 1.57 \\
Junior high school & 437,698 & 0.52 & 445,507 & 1.78 \\
Primary school, Supplementary school and illiteracy & 329,346 & -0.17 & 327,422 & -0.58 \\
\hline
\end{tabular}

Source: Directorate General of Budget, Accounting and Statistics (DGBAS) of Executive Yuan, R. O. C. (Taiwan)

Taiwan has experienced a rise in income inequality over the past decades. The widening dispersion in income is shaped by the increasing concentration of income at the top end of the income distribution. The income of the bottom quintile of Taiwan stagnated during the 2010s while that of the top quintile surged. In 1970, for example, the highest $20 \%$ of households consumed 38.69 percent of disposable Income of households; by 2016, that share slightly increased to 40.36 percent. The ratio of income share of highest $20 \%$ to that of lowest $20 \%$ increased from 4.58 in 1970 to 6.08 in 2016. The share of income going to the top earners has risen sharply in Taiwan. Taiwan was not only producing more poor; the poor were also getting poorer relative to everyone else. We have seen three decades of stagnant real wages for most workers despite rapid productivity growth and greater inequality. These problems get worse in societies that experience an increase in inequality. Since the 1980s, technological change has been concentrated in capital goods utilized by skilled workers. The increase in productivity from computers, the internet, and other similar technologies is exclusively captured by high skilled workers. The difference between wages for high and low skilled workers has increased since the 1980s. Skill biased technological change (SBTC) seems to explain the rapid increase in wage inequality. Wage income inequality depends on the relative progress of education and technology.

The idea that education is the means to social mobility has been around for a long time. Taiwan has acted to assure greater intergenerational advancement for the disadvantaged through education. Between 1968 and 2016, Taiwan undertook significant school reform to provide equal educational opportunities to all students irrespective of place of residence or social background. Taiwan implemented a unified curriculum for all students until age 18. It also postponed the age at which students are tracked according to their abilities, from age 12 to 15 . Taiwan has adjusted their programs to avoid the pitfalls apparent in early tracking. The age of choice of educational track is a prime target for reform to improve social mobility. Government makes education a key lever to provide opportunities to children of all social strata and to spur economic growth. It was thought that higher supply would increase equality of opportunities, and contribute to the creation of a more just system, with beneficial effects on social mobility. The efficiency of an education system should be measured in terms of the amount of social and occupational mobility. Schools work effectively when they enable students to achieve occupational and educational goals regardless of family background. Social mobility in increasingly knowledge-driven economies is powerfully linked to equitable access to higher education. Social mobility requires equally large-scale changes in the occupational structure, particularly if the education system is expanding. Policies aimed at enhancing social mobility, consider their links with future educational choices and equal opportunity for individuals.

A massive flow of foreign direct investment has triggered the process of technological change, and generated the need for skill upgrading of the workforce, especially of the youngest segments. Young people today must negotiate the new terrain of a life course that is unpredictable. The shift into postindustrial society has changed the nature of work, with the emergence of flexible and precarious employment in place of a career for life. As a result from the financial crisis, the worsened situation on the labor market reinforces the challenges to find meaningful education or labor. A stronger focus is now placed on the youth, education and better skill matching, as well as on labour market transitions. In the analysis of the current weaknesses of Taiwan labour market, Taiwan focuses on the need to improve employability (in particular of young people) and on the development of skills relevant for the labour market. Investments in human capital that enhance the development of competencies might well be perceived as investments in an area with relatively high social and economic returns. Such as the expansion of higher education and raising the age of compulsory participation in education or training, these measures were underpinned by 
the view that social problems such as unemployment, poverty and social inequality could be alleviated by transforming them into problems of educational access, achievement and quality. Attainment levels in higher education in Taiwan meets the projected growth in knowledge-intensive jobs, reinforce Taiwan's capacity to benefit from globalization. This puts schools in a very important position through their role in education of youth and in turn the future employment of young people.

Table 15 illustrates the trends in the "International Mathematics and Science Study, end of 2015". Taiwan ranked third for both items of 8th Grade Mathematics and 8th Grade Science compared with fourth and sixth respectively, for 4th Grade Mathematics and for 4th Grade Science. Table 16 illustrates changes in the "Reading, Math and Science Scores of 15-Year-Olds on the PISA, end of 2015". Taiwan ranked $23^{\text {th }}$ for Reading compared with fourth and fourth respectively, for Mathematics and Science. The deterioration of students' scholastic abilities has been discussed intensively in the context of the deterioration of fundamental literacy skills. In an attempt to regain Taiwan status in reading skills in the world rankings, policies were developed to improve literacy skills. Many teachers encouraged their students to read more books and they developed learning materials to improve students' reading skills. PISA has been introduced to create a change in the education system, which is based on a different type of education system in the global society. PISA seems to play a part in bringing this educational globalization about, and students can aspire for a better international career when they get higher scores in PISA tests.

Table 15. Trends in International Mathematics and Science Study, End of 2015.

\begin{tabular}{|c|c|c|c|c|c|c|c|c|}
\hline \multirow{2}{*}{ Rank } & \multicolumn{2}{|c|}{ 8th Grade Mathematics } & \multicolumn{2}{|c|}{ 8th Grade Science } & \multicolumn{2}{|c|}{ 4th Grade Mathematics } & \multicolumn{2}{|c|}{ 4th Grade Science } \\
\hline & Country & Mean Score & Country & Mean Score & Country & Mean Score & Country & Mean Score \\
\hline 1 & Singapore & 621 & Singapore & 597 & Singapore & 618 & Singapore & 590 \\
\hline 2 & South Korea & 606 & Japan & 571 & Hong Kong & 615 & South Korea & 589 \\
\hline 3 & R. O. C. Taiwan & 599 & R. O. C. Taiwan & 569 & South Korea & 608 & Japan & 569 \\
\hline 4 & Hong Kong & 594 & South Korea & 556 & R. O. C. Taiwan & 597 & Russia & 567 \\
\hline 5 & Japan & 586 & Slovenia & 551 & Japan & 593 & Hong Kong & 557 \\
\hline 6 & Russia & 538 & Hong Kong & 546 & Northern Ireland & 570 & R. O. C. Taiwan & 555 \\
\hline 8 & Canada & 527 & England & 537 & Norway & 549 & Kazakhstan & 550 \\
\hline 9 & Ireland & 523 & Kazakhstan & 533 & Ireland & 547 & Poland & 547 \\
\hline 10 & United States & 518 & Ireland & 530 & England & 546 & United States & 546 \\
\hline 11 & England & 518 & United States & 530 & Belgium & 546 & Slovenia & 543 \\
\hline 12 & Slovenia & 516 & Hungary & 527 & Kazakhstan & 544 & Hungary & 542 \\
\hline 13 & Hungary & 514 & Canada & 526 & Portugal & 541 & Sweden & 540 \\
\hline 14 & Norway & 512 & Sweden & 522 & United States & 539 & Norway & 538 \\
\hline 16 & Israel & 511 & New Zealand & 513 & Lithuania & 535 & Bulgaria & 536 \\
\hline 17 & Australia & 505 & Australia & 512 & Finland & 535 & Czech & 534 \\
\hline 18 & Sweden & 501 & Norway & 509 & Poland & 535 & Croatia & 533 \\
\hline 19 & Italy & 494 & Israel & 507 & Netherlands & 530 & Ireland & 529 \\
\hline 20 & Republic of Malta & 494 & Italy & 499 & Hungary & 529 & Germany & 528 \\
\hline
\end{tabular}

Source: Ministry of Education, R. O. C. (Taiwan)

Unit: Score

Table 16. Reading, Math and Science Scores of 15-Year-Olds on the PISA, End of 2015.

\begin{tabular}{|c|c|c|c|c|c|c|c|c|c|}
\hline \multirow{2}{*}{ Rank } & \multirow{2}{*}{ Country } & \multicolumn{2}{|c|}{ Reading } & \multirow{2}{*}{ Country } & \multicolumn{2}{|c|}{ Mathematics } & \multirow{2}{*}{ Country } & \multicolumn{2}{|c|}{ Science } \\
\hline & & Mean & S. E. & & Mean & S. E. & & Mean & S. E. \\
\hline 1 & Singapore & 535 & 1.6 & Singapore & 564 & 1.5 & Singapore & 556 & 1.2 \\
\hline 2 & Hong Kong & 527 & 2.7 & Hong Kong & 548 & 3.0 & Japan & 538 & 3.0 \\
\hline 3 & Canada & 527 & 2.3 & Macao & 544 & 1.1 & Estonia & 534 & 2.1 \\
\hline 4 & Finland & 526 & 2.5 & R. O. C. Taiwan & 542 & 3.0 & R. O. C. Taiwan & 532 & 2.7 \\
\hline 5 & Ireland & 521 & 2.5 & Japan & 532 & 3.0 & Finland & 531 & 2.4 \\
\hline 6 & Estonia & 519 & 2.2 & China (B-S-J-G) & 531 & 4.9 & Macao & 529 & 1.1 \\
\hline 7 & South Korea & 517 & 3.5 & South Korea & 524 & 3.7 & Canada & 528 & 2.1 \\
\hline 8 & Japan & 516 & 3.2 & Switzerland & 521 & 2.9 & Vietnam & 525 & 3.9 \\
\hline 9 & Norway & 513 & 2.5 & Estonia & 520 & 2.0 & Hong Kong & 523 & 2.5 \\
\hline 10 & New Zealand & 509 & 2.4 & Canada & 516 & 2.3 & China (B-S-J-G) & 518 & 4.6 \\
\hline 11 & Germany & 509 & 3.0 & Netherlands & 512 & 2.2 & South Korea & 516 & 3.1 \\
\hline 12 & Macao & 509 & 1.3 & Denmark & 511 & 2.2 & New Zealand & 513 & 2.4 \\
\hline 13 & Poland & 506 & 2.5 & Finland & 511 & 2.3 & Slovenia & 513 & 1.3 \\
\hline 14 & Slovenia & 505 & 1.5 & Slovenia & 510 & 1.3 & Australia & 510 & 1.5 \\
\hline 15 & Netherlands & 503 & 2.4 & Belgium & 507 & 2.4 & United Kingdom & 509 & 2.6 \\
\hline 16 & Australia & 503 & 1.7 & Germany & 506 & 2.9 & Germany & 509 & 2.7 \\
\hline 17 & Sweden & 500 & 3.5 & Poland & 504 & 2.4 & Netherlands & 509 & 2.3 \\
\hline
\end{tabular}




\begin{tabular}{|c|c|c|c|c|c|c|c|c|c|}
\hline \multirow{2}{*}{ Rank } & \multirow{2}{*}{ Country } & \multicolumn{2}{|c|}{ Reading } & \multirow{2}{*}{ Country } & \multicolumn{2}{|c|}{ Mathematics } & \multirow{2}{*}{ Country } & \multicolumn{2}{|c|}{ Science } \\
\hline & & Mean & S. E. & & Mean & S. E. & & Mean & S. E. \\
\hline 18 & Denmark & 500 & 2.5 & Ireland & 504 & 2.1 & Switzerland & 506 & 2.9 \\
\hline 19 & France & 499 & 2.5 & Norway & 502 & 2.2 & Ireland & 503 & 2.4 \\
\hline 20 & Belgium & 499 & 2.4 & Austria & 497 & 2.9 & Belgium & 502 & 2.3 \\
\hline 21 & Portugal & 498 & 2.7 & New Zealand & 495 & 2.3 & Denmark & 502 & 2.4 \\
\hline 22 & United Kingdom & 498 & 2.8 & Vietnam & 495 & 4.5 & Poland & 501 & 2.5 \\
\hline 23 & R. O. C. Taiwan & 497 & 2.5 & Russia & 494 & 3.1 & Portugal & 501 & 2.4 \\
\hline 24 & United States & 497 & 3.4 & Sweden & 494 & 3.2 & Norway & 498 & 2.3 \\
\hline 25 & Spain & 496 & 2.4 & Australia & 494 & 1.6 & United States & 496 & 3.2 \\
\hline 26 & Russia & 495 & 3.1 & France & 493 & 2.1 & Austria & 495 & 2.4 \\
\hline 27 & China (B-S-J-G) & 494 & 5.1 & United Kingdom & 492 & 2.5 & France & 495 & 2.1 \\
\hline 28 & Switzerland & 492 & 3.0 & Czech Republic & 492 & 2.4 & Sweden & 493 & 3.6 \\
\hline 29 & Latvia & 488 & 1.8 & Portugal & 492 & 2.5 & Czech Republic & 493 & 2.3 \\
\hline \multirow[t]{2}{*}{30} & Czech Republic & 487 & 2.6 & Italy & 490 & 2.8 & Spain & 493 & 2.1 \\
\hline & OECD (Ave.) & 493 & 0.5 & OECD (Ave.) & 490 & 0.4 & OECD (Ave.) & 493 & 0.4 \\
\hline
\end{tabular}

Source: Ministry of Education, R. O. C. (Taiwan)

Unit: Score

Table 17 illustrates the input of education and rsearch in Taiwan. The tertiary education gross enrollment ratios (\%) develops from 47.0 in 1998 to 83.9 in 2013; the number of students per teacher-primary education (person) develops from 20.1 in 1998 to 13.3 in 2013; the expenditure on educational institutions as\% GDP (\%) decreases from 6.3 in 1998 to 5.7 in 2013; the government expenditure on educational institutions as\% GDP (\%) decreases from 4.8 in 1998 to 3.7 in 2013; the number of annual papers in SCI (paper) develops from 8886 in 1998 to 27,699 in 2013; the number of U.S. patents granted (paper) develops from 3100 in 1998 to 11,071 in 2013. Taiwan has a multiple admission program. The education system makes sense only when children achieve the results necessary for passing the entrance examination of good schools or universities. Table 18 illustrates the annual papers and rank by nationality in SCI and SSCI. In 2015, Taiwan 21th for SCI compared with 17th for SSCI. Table 19 makes international comparison by items, including population, fertility rate, education and rsearch, enrollment ratio, expenditure on education, papers in SCI, patents, employment, and labor force, etc. It would be of value if social systems theory was applied not only to Taiwan society but also to the international or global society. In the context of globalization, those who are globally competent have greater possibilities to obtain a better social status in the world. Taiwan education policy becomes increasingly influenced by global organizations.

Table 17. Education and Research in Taiwan, End of 1998-2013.

\begin{tabular}{llllll}
\hline year & $\begin{array}{l}\text { Tertiary education } \\
\text { gross enrollment } \\
\text { ratios (\%) }\end{array}$ & $\begin{array}{l}\text { Number of students per } \\
\text { teacher - Primary } \\
\text { education (person) }\end{array}$ & $\begin{array}{l}\text { Expenditure on } \\
\text { educational institutions } \\
\text { as\% GDP (\%) }\end{array}$ & $\begin{array}{l}\text { Government expenditure } \\
\text { on educational institutions } \\
\text { as\% GDP (\%) }\end{array}$ & $\begin{array}{l}\text { Number of } \\
\text { annual papers in } \\
\text { SCI (paper) }\end{array}$ \\
\hline 1998 & 47.0 & 20.1 & 6.3 & 4.8 & $\begin{array}{l}\text { Number of U.S. } \\
\text { patents granted } \\
\text { (paper) }\end{array}$ \\
2009 & 82.2 & 16.1 & 6.3 & 4.3 & 3886 \\
2010 & 83.8 & 15.3 & 5.7 & 3.8 & 23778 \\
2013 & 83.9 & 13.3 & 5.7 & 3.7 & 24921 \\
\hline
\end{tabular}

Source: Directorate General of Budget, Accounting and Statistics (DGBAS) of Executive Yuan, R. O. C. (Taiwan)

Table 18. Annual Papers and Rank by Nationality in SCI and SSCI, End of 2015.

\begin{tabular}{|c|c|c|c|c|c|}
\hline \multirow{2}{*}{ Nationality } & \multicolumn{2}{|l|}{ in SCI } & \multirow{2}{*}{ Nationality } & \multicolumn{2}{|l|}{ in SSCI } \\
\hline & Paper & Rank & & Paper & Rank \\
\hline United States & 421,397 & 1 & United States & 105,627 & 1 \\
\hline Mainland China & 294,751 & 2 & United Kingdom & 35,163 & 2 \\
\hline United Kingdom & 124,261 & 3 & Australia & 18,413 & 3 \\
\hline Germany & 110,448 & 4 & Canada & 16,058 & 4 \\
\hline Japan & 78,413 & 5 & Germany & 14,732 & 5 \\
\hline France & 76,032 & 6 & Mainland China & 12,257 & 6 \\
\hline Canada & 70,097 & 7 & Netherlands & 10,684 & 7 \\
\hline Italy & 68,709 & 8 & Spain & 9,010 & 8 \\
\hline Australia & 64,717 & 9 & Italy & 7,608 & 9 \\
\hline India & 62,123 & 10 & France & 6,873 & 10 \\
\hline Spain & 59,310 & 11 & Sweden & 5,638 & 11 \\
\hline South Korea & 58,164 & 12 & Switzerland & 4,673 & 12 \\
\hline Brazil & 43,635 & 13 & Brazil & 4,117 & 13 \\
\hline Netherlands & 41,142 & 14 & Belgium & 4,057 & 14 \\
\hline Russia & 35,387 & 15 & South Korea & 3,991 & 15 \\
\hline Switzerland & 30,745 & 16 & Japan & 3,806 & 16 \\
\hline
\end{tabular}




\begin{tabular}{|c|c|c|c|c|c|}
\hline \multirow{2}{*}{ Nationality } & \multicolumn{2}{|l|}{ in SCI } & \multirow{2}{*}{ Nationality } & \multicolumn{2}{|c|}{ in SSCI } \\
\hline & Paper & Rank & & Paper & Rank \\
\hline Iran & 29,695 & 17 & R. O. C. Taiwan & 3,645 & 17 \\
\hline Turkey & 29,185 & 18 & Denmark & 3,448 & 18 \\
\hline Poland & 28,123 & 19 & Norway & 3,408 & 19 \\
\hline Sweden & 27,701 & 20 & South Africa & 3,133 & 20 \\
\hline R. O. C. Taiwan & 26,715 & 21 & Turkey & 3,079 & 21 \\
\hline Belgium & 23,220 & 22 & India & 3,052 & 22 \\
\hline Denmark & 18,819 & 23 & Israel & 2,878 & 23 \\
\hline Austria & 15,968 & 24 & Finland & 2,598 & 24 \\
\hline Israel & 14,843 & 25 & New Zealand & 2,579 & 25 \\
\hline Portugal & 14,705 & 26 & Austria & 2,080 & 26 \\
\hline Mexico & 13,878 & 27 & Portugal & 2,077 & 27 \\
\hline Kingdom of Saudi Arabia & 13,775 & 28 & Singapore & 2,041 & 28 \\
\hline Singapore & 13,749 & 29 & Ireland & 1,899 & 29 \\
\hline Finland & 13,630 & 30 & Poland & 1,591 & 30 \\
\hline
\end{tabular}

Source: Ministry of Education, R. O. C. (Taiwan)

Unit: Paper

Table 19. International Comparison.

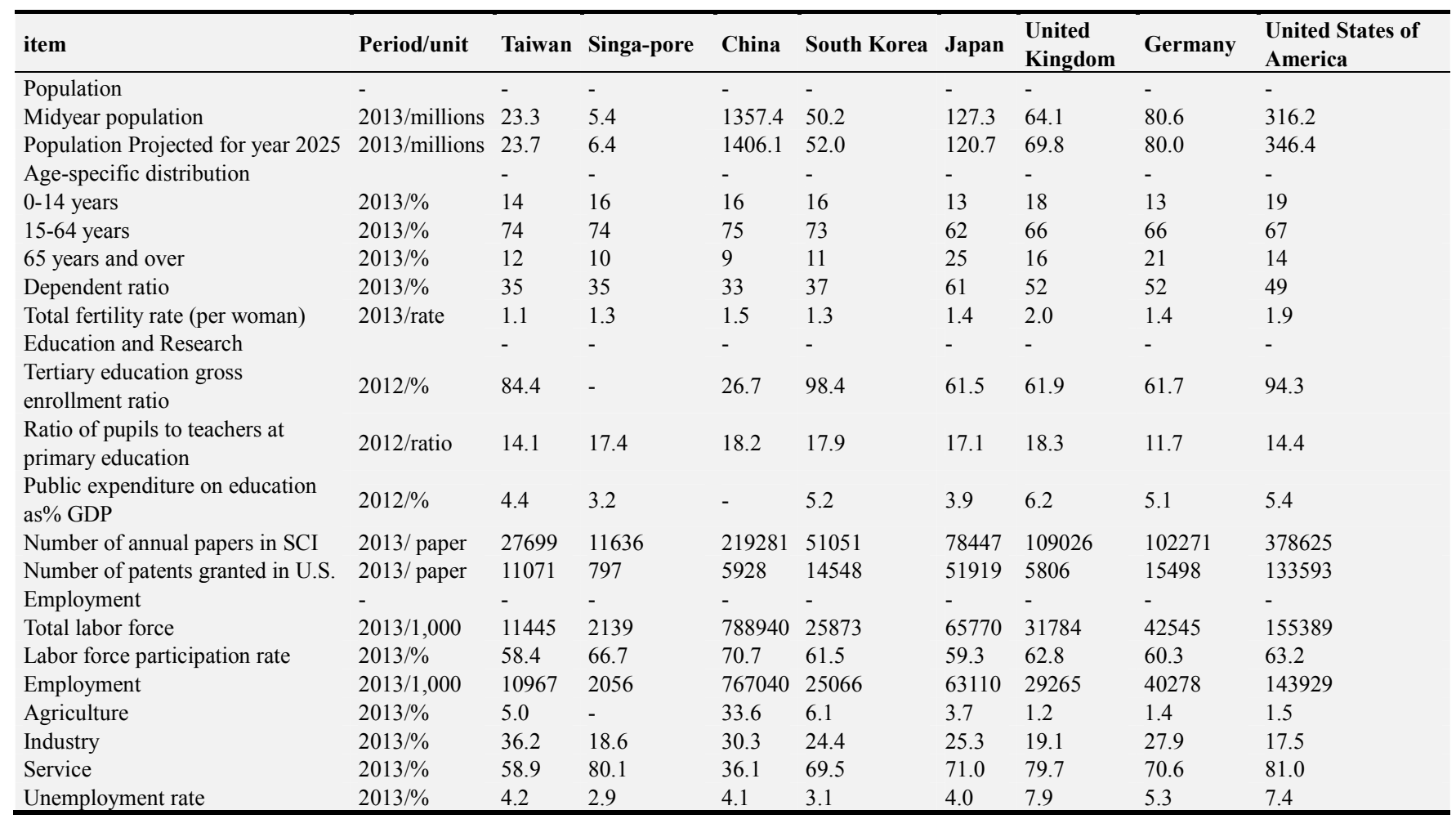

Source: Directorate General of Budget, Accounting and Statistics (DGBAS) of Executive Yuan, R. O. C. (Taiwan)

Notice: "-" means "No such item".

\section{Discussion}

The potential positive effects of capital flows include technology transfers, skill upgradation, and expanding its stock of human capital. The global economy is in the midst of change process affecting access to knowledge and technology. Globalization has defined new rules for competition of workers. It is essential to know how to attract, develop and retain intellectual capital. The local communities developed their distinctive social and political practices through their social diversity. Education must admit competent students from all sectors of the culturally diverse society. It deserves to highlight the place of education in multicultural policies, and to reflect upon the debates about the future of multiculturalism and social equality. For the ageing society, activation policies have become a matter of growing importance in response to the converging pressure of economic globalisation and the political modernisation of social welfare. Given the persistent high youth unemployment rates, a focus is now placed on the youth, education and better skill matching, as well as on labour market transitions. Thus, employment policies should be undergone reforms.

Rising demand for skilled labor is rooted in a permanent change in the structure of the global economy. Analysis of 
contemporary education policy reveals a concern with transforming education in the face of daunting challenges linked to globalization. Education is now seen as a vehicle of national competitiveness in which the economic policies have focused on the need for competitive human capital. The pressure resulting from expanding global competition has provoked educational reform measures that are focused on improving the quality of the labor force. The local communities need to think about closing the skills gap if they wish to continue to grow and develop employment opportunities. Education is a good investment for social mobility. To finish the job of increasing mobility, we must urge reform to improve educational mobility. We must lift up students who have the potential, whatever their parents' income, educational, or socioeconomic background, to realize the brightest possible future for our societies and economies. The government should target education as a way to improve social mobility and in turn bring more vitality to local economies.

High youth unemployment rates and a significant degree of instability in employment paths have become key characteristics of the societies. The inclusion of young people from disadvantaged backgrounds has become a priority on the agenda of the local. Rigid educational systems impose constraints on individual decisions of investment in human capital, and may affect negatively the transition from education to work. The coming decades are likely to be challenging times for researchers to comprehend the transformations occurring around and in relation to youth. Education is held to be desirable even beyond its role in fostering economic growth, further social integration and mobility, increasing productivity and promoting social justice. The government should make education a key lever to provide opportunities to children of all social strata and to spur economic growth. But the use of education to spur mobility is not straightforward and remains complicated by a number of social, financial, and political factors. Inequality remains a major challenge to development and the elimination of poverty.

\section{Conclusions}

This geo-political shift has been configured in terms of attenuating flows of capital and cross-border movement. Labor market mobility is likely to contribute to the development and accumulation of skills needed for innovations. In an intensifying global competition the talent, the labour markets should continue to absorb the increased supply of higher-educated workers. The importance of investments in human capital in offsetting the negative socioeconomic consequences of population ageing shoule be underlined. Due to the progressive ageing of the society and the consequent decrease in economically active population, the local communities shall particularly focus on the improvement of the quality of its education and vocational training system as well as on tackling the problems associated with the growing number of young people excluded not only from the labour market but from the integration into the society at large. Policy makers need to realize that to overcome the possible future consequences of ageing, and appropriate measures should be implemented soon.

Openness to new ideas, collaborations, and the development of absorptive capacities are the cornerstones of a successful innovation strategy. Higher education policy needs to be coordinated with a wider set of innovation policies. A principal task for higher education is to contribute to collective entrepreneurship, to general skills supporting interaction with others resulting in innovation. Public policies should be guided towards the creation of innovation flows and schools should teach young people how to be creative and resourceful, as these qualities are indispensable to promote entrepreneurialism. Educational strategies in the form of investments in human capital are increasingly regarded as the primary means to tackle the challenges of demographic and technological change but also the risk of social disruption. The government should present the solutions to the escalating demands of globalization and growing levels of economic competition.

\section{References}

[1] Kry'nska ElPzbieta (2013). Critical Assessment of Labour Force Evolution in Europe. In Marek Kupiszewski (ed.), International migration and the future of populations and labour force resources in Europe (269-292). Dordrecht; Springer Netherlands; Imprint: Springer. ISBN: 9789048189472 (Print) 9789048189489 (Online).

[2] Beck T., Claessens S., Schmukler S. L. (2013). Financial Globalization and Crises: Overview. In Gerard Caprio, Thorsten Beck, Stijn Claessens, Sergio L. Schmukler (ed.), The evidence and impact of financial globalization (1-12). Boston; Academic Press. ISBN: 9780123978745.

[3] Aykut D., Kose M. A. (2013). Collateral Benefits of Financial Globalization. In Gerard Caprio, Thorsten Beck, Stijn Claessens, Sergio L. Schmukler (ed.), The evidence and impact of financial globalization (279-297). Boston; Academic Press. ISBN: 9780123978745.

[4] Ghosh Bimal (2013). The global economic crisis and the future of migration; issues and prospects; what will migration look like in 2045? Palgrave Macmillan. ISBN: 9781349338238 (Print) 9781137291301 (Online).

[5] Sánchez-Zarza Domingo and Saiz-Álvarez José Manuel (2014). Intellectual Expatriates and Their Intangible Value in Post-Industrial Globalized Societies. In Louis Brennan (ed.), Enacting globalization; multidisciplinary perspectives on international integration (263-272). Palgrave Macmillan. ISBN: 9781349472468 (Print) 9781137361943 (Online).

[6] Teltemann Janna and Windzio Michael (2013). SocioStructural Effects on Educational Poverty of Young Immigrants: An International Comparative Perspective. In Michael Windzio (ed.), Integration and inequality in educational institutions (99-122). Dordrecht; Springer Netherlands; Imprint: Springer. ISBN: 9789400761186 (Print) 9789400761193 (Online). 
[7] Lane Philip R. (2014). Reflections on Capital Flows in the Euro Area. In Louis Brennan (ed.), Enacting globalization; multidisciplinary perspectives on international integration (219-229). Palgrave Macmillan. ISBN: 9781349472468 (Print) 9781137361943 (Online).

[8] Saczuk Katarzyna (2013B). Labour Force Participation Scenarios for 27 European Countries, 2002 -2052. In Marek Kupiszewski (ed.), International migration and the future of populations and labour force resources in Europe (173-192). Dordrecht; Springer Netherlands; Imprint: Springer. ISBN: 9789048189472 (Print) 9789048189489 (Online).

[9] Ziegler Holger, Berthet Thierry, Atzmüller Roland, Bonvin Jean-Michel, and Kjeldsen Christian Christrup (2015). Towards a Capabilities Perspective on Vulnerable Young People in Europe: An Introduction. In Hans-Uwe Otto et al. (ed.), Facing Trajectories from School to Work; towards a capability-friendly youth policy in Europe (3-18). Technical and Vocational Education and Training: Issues, Concerns and Prospects 20. Springer International Publishing Switzerland. ISBN: 9783319114354 (Print) 9783319114361 (Online).

[10] Halbert Debora (2015). Reshaping Higher Education for a Globalized Future. In Deane E. Neubauer and Kamila Ghazali (ed.), Technology and workplace skills for the twenty-first century; Asia Pacific universities in the globalized economy (49-70). New York; Palgrave Macmillan US; Imprint: Palgrave Macmillan. ISBN: 9781349573714 (Print) 9781137491923 (Online).

[11] Kaufmann Vincent and Viry Gil (2015). High Mobility as Social Phenomenon. In Gil Viry and Vincent Kaufmann (ed.), High mobility in Europe; work and personal life (1-15). London; Palgrave Macmillan UK; Imprint: Palgrave Macmillan. ISBN: 9781349562596 (Print) 9781137447388 (Online).

[12] Lorenz Edward (2012). Labor Market Institutions, Skills, and Innovation Style: A Critique of the 'Varieties of Capitalism' Perspective. In Bjørn T. Asheim and Mario Davide Parrilli (ed.), Interactive Learning for Innovation. A Key Driver within Clusters and Innovation Systems. (72-89). Palgrave Macmillan. ISBN 9781349335008 ISBN 9780230362420 (eBook).

[13] Magnani Marco (2014). Creating economic growth; lessons for Europe. Basingstoke; Palgrave Macmillan. ISBN: 9781349490998 (Print) 9781137427052 (Online).

[14] Viry Gil and Vincent-Geslin Stéphanie (2015). High Mobility Over the Life Course. In Gil Viry and Vincent Kaufmann (ed.), High mobility in Europe; work and personal life (83-100). London: Palgrave Macmillan UK; Imprint: Palgrave Macmillan. ISBN: 9781349562596 (Print) 9781137447388 (Online).

[15] Cooke Philip (2012). Knowledge Economy Spillovers, Proximity, and Specialization. In Bjørn T. Asheim and Mario Davide Parrilli (ed.), Interactive Learning for Innovation. A Key Driver within Clusters and Innovation Systems. (100114). Palgrave Macmillan. ISBN 9781349335008 ISBN 9780230362420 (eBook).

[16] Pereira Dina and Leitão João (2015). Coopetition and Open Innovation: An Application to KIS vs. Less-KIS Firms. In Rui Baptista and João Leitão (ed.), Entrepreneurship, human capital, and regional development; labor networks, knowledge flows, and industry growth (169-186). Springer International Publishing Switzerland. ISBN: 9783319128702 (Print) 9783319128719 (Online).
[17] Bogas Patrícia and Barbosa Natália (2015). High-Growth Firms: What Is the Impact of Region-Specific Characteristics? In Rui Baptista and João Leitão (ed.), Entrepreneurship, human capital, and regional development; labor networks, knowledge flows, and industry growth (295-308). Springer International Publishing Switzerland. ISBN: 9783319128702 (Print) 9783319128719 (Online).

[18] Alfaro L. and Johnson M. S. (2013). Foreign Direct Investment and Growth. In Gerard Caprio, Thorsten Beck, Stijn Claessens, Sergio L. Schmukler (ed.), The evidence and impact of financial globalization (299-308). Boston; Academic Press. ISBN: 9780123978745.

[19] Michailova Snejina and Chetty Sylvie (2011). Cluster Membership, Knowledge and SMEs' Internationalization. In Martin Johanson and Heléne Lundberg (ed.), Network Strategies for Regional Growth (126-150). Palgrave Macmillan. ISBN 9781349323838 ISBN 9780230299146 (eBook).

[20] Tinguely Xavier (2013). The New Geography of Innovation. Clusters, Competitiveness and Theory. Palgrave Macmillan. ISBN 9781349474394 ISBN 9781137367136 (eBook).

[21] Dulupçu Murat Ali, Karaöz Murat, Sungur Onur, and Ünlü Hidayet (2015). Cluster (ing) Policies in Turkey: The Impact of Internationalization or the Imitation of Internationals. In Rui Baptista and João Leitão (ed.), Entrepreneurship, human capital, and regional development; labor networks, knowledge flows, and industry growth (239-262). Springer International Publishing Switzerland. ISBN: 9783319128702 (Print) 9783319128719 (Online).

[22] Araya Daniel (2015). Rethinking US education policy; paradigms of the knowledge economy. New York; Palgrave Macmillan US; Imprint: Palgrave Macmillan. ISBN: 9781349692972 (Print) 9781137475565 (Online).

[23] Cabrita Maria Rosário, Cabrita Cristina, Matos Florinda, and Dueñas María del Pilar Muñoz (2015). Entrepreneurship Capital and Regional Development: A Perspective Based on Intellectual Capital. In Rui Baptista and João Leitão (ed.), Entrepreneurship, human capital, and regional development; labor networks, knowledge flows, and industry growth (15-28). Springer International Publishing Switzerland. ISBN: 9783319128702 (Print) 9783319128719 (Online).

[24] Olim André, Mota Isabel, and Silva Sandra T. (2015). The Influence of Creativity on Entrepreneurship: The Portuguese Case. In Rui Baptista and João Leitão (ed.), Entrepreneurship, human capital, and regional development; labor networks, knowledge flows, and industry growth (205-235). Springer International Publishing Switzerland. ISBN: 9783319128702 (Print) 9783319128719 (Online).

[25] Francois Emmanuel Jean (2015). Building global education with a local perspective; an introduction to glocal higher education. New York; Palgrave Macmillan US; Imprint: Palgrave Macmillan. ISBN: 9781349483075 (Print) 9781137386779 (Online).

[26] Asheim Bjørn T. and Parrilli Mario Davide (2012). Introduction: Learning and Interaction - Drivers for Innovation in Current Competitive Markets. In Bjørn $T$. Asheim and Mario Davide Parrilli (ed.), Interactive Learning for Innovation. A Key Driver within Clusters and Innovation Systems. (1-32). Palgrave Macmillan. ISBN 9781349335008 ISBN 9780230362420 (eBook). 
[27] Aliaga-Isla Rocío (2015). Does Human Capital Impact Differently the Opportunity Perception and the Business Creation? The Case of Spain. In Rui Baptista and João Leitão (ed.), Entrepreneurship, human capital, and regional development; labor networks, knowledge flows, and industry growth (187-204). Springer International Publishing Switzerland. ISBN: 9783319128702 (Print) 9783319128719 (Online).

[28] Kwiek Marek (2015). European Universities and Educational and Occupational Intergenerational Social Mobility. In HansUwe Otto et al. (ed.), Facing Trajectories from School to Work; towards a capability-friendly youth policy in Europe (87-114). Technical and Vocational Education and Training: Issues, Concerns and Prospects 20. Springer International Publishing Switzerland. ISBN: 9783319114354 (Print) 9783319114361 (Online).

[29] Mau Steffen (2015). Inequality, Marketization and the Majority Class: Why Did the European Middle Classes Accept Neo-Liberalism? London; Palgrave Macmillan UK; Imprint: Palgrave Pivot. ISBN: 9781349506262 (Print) 9781137511614 (Online).

[30] Baptista Rui and Leitão João (2015). Introduction. In Rui Baptista and João Leitão (ed.), Entrepreneurship, human capital, and regional development; labor networks, knowledge flows, and industry growth (1-11). Springer International Publishing Switzerland. ISBN: 9783319128702 (Print) 9783319128719 (Online).
[31] Tholen Gerbrand (2014). The changing nature of the graduate labour market: media, policy and political discourses in the UK. Basingstoke; Palgrave Pivot. ISBN: 9781349502370 (Print) 9781137479075 (Online).

[32] Simmons Robin, Thompson Ron, Russell Lisa (2014). Education, work and social change; young people and marginalisation in post-industrial Britain. Basingstoke; Palgrave Macmillan. ISBN: 9781137335937 (Print) 9781137335944 (Online).

[33] Bilfulco Lavinia, Egdell Valerie, McQuaid Ronald, Berthet Thierry, Simon Véronique, Monteleone Raffaele, Mozzana Carlotta, Rosenstein Emilie, Dif-Pradalier Maël, Bonvin JeanMichel, Hollywood Emma, Jensen Niels Rosendal, Kjeldsen Christian Christrup, Sztandar- Sztanderska Karolina, Zieleńska Marianna, Haidinger Bettina, Kasper Ruth, Düker Jan, Ley Thomas, and Bergström Gunilla (2015). Capabilities for Voice, Work and Education: Critical Analysis of Programmes for Disadvantaged Young People in Europe. In Hans-Uwe Otto et al. (ed.), Facing Trajectories from School to Work; towards a capability-friendly youth policy in Europe (201-360). Technical and Vocational Education and Training: Issues, Concerns and Prospects 20. Springer International Publishing Switzerland. ISBN: 9783319114354 (Print) 9783319114361 (Online). 